\title{
Genome-wide QTL mapping of yield and agronomic traits in two widely adapted winter wheat cultivars from multiple mega-environments
}

Smit Dhakal ${ }^{1}$, Xiaoxiao Liu ${ }^{1}$, Chenggen Chu ${ }^{1,2}{ }^{\text {, Yan Yang }}{ }^{1}$, Jackie C. Rudd ${ }^{1}$, Amir M.H. Ibrahim ${ }^{3}$, Qingwu Xue ${ }^{1}$, Ravindra N. Devkota ${ }^{1}$, Jason A. Baker ${ }^{1}$, Shannon A. Baker ${ }^{1}$, Bryan E. Simoneaux ${ }^{3}$, Geraldine B. Opena ${ }^{3}$, Russell Sutton $^{3}$, Kirk E. Jessup ${ }^{1}$, Kele Hui ${ }^{1}$, Shichen Wang ${ }^{4}$, Charles D. Johnson ${ }^{4}$, Richard P. Metz ${ }^{4}$, Shuyu Liu ${ }^{\text {Corresp. } 1}$

${ }^{1}$ Texas A\&M AgriLife Research and Extension Center, Texas A\&M AgriLife Research, Amarillo, Texas, United States

2 Edward T. Schafer Agricultural Research Center, Sugarbeet \& Potato Research Unit,, USDA-ARS, Fargo, ND, United States

3 Department of Soil and Crop Sciences, Texas A\&M University, College Station, Texas, United States

${ }^{4}$ Genomics and Bioinformatics Service Center, Texas A\&M AgriLife Research, College Station, Texas, United States

Corresponding Author: Shuyu Liu

Email address: SLiu@ag.tamu.edu

Quantitative trait loci (QTL) analysis could help to identify suitable molecular markers for marker-assisted breeding (MAB). A mapping population of $124 F_{5: 7}$ recombinant inbred lines derived from the cross 'TAM 112'/'TAM 111' was grown under 28 diverse environments and evaluated for grain yield, test weight, heading date, and plant height. The objective of this study was to detect QTL conferring grain yield and agronomic traits from multiple mega-environments. Through a linkage map with 5,948 single nucleotide polymorphisms (SNPs), 51 QTL were consistently identified in two or more environments or analyses. Ten QTL linked to two or more traits were also identified on chromosomes 1A, 1D, 4B, 4D, 6A, 7B, and 7D. Those QTL explained up to $13.3 \%$ of additive phenotypic variations with the additive logarithm of odds ( $\operatorname{LOD}(A))$ scores up to 11.2. The additive effect increased yield up to 8.16 and $6.57 \mathrm{~g} \mathrm{~m}^{-2}$ and increased test weight by 2.14 and $3.47 \mathrm{~kg} \mathrm{~m}^{-3}$ with favorable alleles from TAM 111 and TAM 112, respectively. Seven major QTL for yield and six for TW with one in common were of our interest on $M A B$ as they explained $5 \%$ or more phenotypic variations through additive effects. This study confirmed previously identified loci and identified new QTL and the favorable alleles for improving grain yield and agronomic traits. 
1

2

3

4

5

6

7

\section{8}

Genome-wide QTL mapping of yield and agronomic traits in two widely adapted winter wheat cultivars from multiple mega-environments

Smit Dhakal ${ }^{1}$, Xiaoxiao Liu ${ }^{1}$, Chenggen Chu ${ }^{1}$, Yan Yang ${ }^{1}$, Jackie C. Rudd ${ }^{1}$, Amir M.H. Ibrahim $^{2}$, Qingwu Xue ${ }^{1}$, Ravindra N. Devkota ${ }^{1}$, Jason A. Baker ${ }^{1}$, Shannon A. Baker ${ }^{1}$, Bryan E. Simoneaux ${ }^{2}$, Geraldine B. Opena ${ }^{2}$, Russell L. Sutton ${ }^{2}$, Kirk E. Jessup ${ }^{1}$, Kele Hui ${ }^{1}$, Shichen Wang ${ }^{3}$, Charles D. Johnson ${ }^{3}$, Richard P. Metz ${ }^{3}$, and Shuyu Liu ${ }^{1}$

${ }^{1}$ Texas A\&M AgriLife Research and Extension Center, Texas A\&M AgriLife Research, Amarillo, TX 79106, USA

${ }^{2}$ USDA-ARS, Edward T. Schafer Agricultural Research Center, Sugarbeet \& Potato Research Unit, Fargo, ND 58102

${ }^{3}$ Department of Soil and Crop Sciences, Texas A\&M University, College Station, TX 77843, USA

${ }^{4}$ Genomics and Bioinformatics Service, Texas A\&M AgriLife Research, College Station, TX 77845 , USA

Corresponding Author:

Shuyu Liu: SLiu@ag.tamu.edu

\section{Abstract}

Quantitative trait loci (QTL) analysis could help to identify suitable molecular markers for marker-assisted breeding (MAB). A mapping population of $124 \mathrm{~F}_{5: 7}$ recombinant inbred lines derived from the cross 'TAM 112'/‘TAM 111' was grown under 28 diverse environments and evaluated for grain yield, test weight, heading date, and plant height. The objective of this study was to detect QTL conferring grain yield and agronomic traits from multiple megaenvironments. Through a linkage map with 5,948 single nucleotide polymorphisms (SNPs), 51 QTL were consistently identified in two or more environments or analyses. Ten QTL linked to two or more traits were also identified on chromosomes 1A, 1D, 4B, 4D, 6A, 7B, and 7D. Those QTL explained up to $13.3 \%$ of additive phenotypic variations with the additive logarithm of odds 
$34(\mathrm{LOD}(\mathrm{A}))$ scores up to 11.2. The additive effect increased yield up to 8.16 and $6.57 \mathrm{~g} \mathrm{~m}^{-2}$ and

35 increased test weight by 2.14 and $3.47 \mathrm{~kg} \mathrm{~m}^{-3}$ with favorable alleles from TAM 111 and TAM

36 112, respectively. Seven major QTL for yield and six for TW with one in common were of our

37 interest on MAB as they explained 5\% or more phenotypic variations through additive effects.

38 This study confirmed previously identified loci and identified new QTL and the favorable alleles

39 for improving grain yield and agronomic traits.

40

41

42

43

\section{Introduction}

Grain yield in wheat (Triticum aestivum L.) is a major goal of most of the wheat breeding programs, particularly in rainfed growing areas (Brinton et al., 2017). In the Southern High Plains, bread wheat is grown under a wide range of mega environments that differ for soil moisture and rainfall pattern. Besides genetic and environmental factors, grain yield is also influenced by agronomic and morphological traits like heading date and plant height (Chen et al., 2012; Liu et al., 2015). Genetic gains in grain yield have been attributed to the development and deployment of high-yielding wheat varieties with improved agronomic traits related to high yield potential (De Vita et al., 2007; Gao et al., 2017; Lopes et al., 2012). Due to their high heritability and correlation with grain yield, agronomic traits such as heading date and plant height are important traits to be considered during breeding and cultivar development (Chen et al., 2012;

Gao et al., 2017; Liu et al., 2015).

Plant height is controlled by many reduced height $(R h t)$ genes that play roles on reducing the length of coleoptile and internode and thus decrease plant height (Rebetzke et al., 2012). Higher grain yield can be achieved by reducing the internal competition to increase assimilate partitioning to the economic sinks and the straw strength (Addisu et al., 2010; Borlaug, 1968; Grover et al., 2018; Worland, 1996). Heading date is influenced by Vrn, Ppd and Efl genes 
58 governing vernalization, photoperiod response, intrinsic earliness, and their interactions (Mondal 59 et al., 2016; Scarth \& Law, 1984; Sourdille et al., 2000; Worland et al., 1998). Test weight (TW, 60 also called grain volume weight) is a volumetric measurement (mass/volume) determined by 61 weighing grain samples filled in a standard dry one-quart measure. TW is a trait directly 62 associated with grain quality and an indirect indicator of seed size and shape that ultimately 63 affects kernel weight (Campbell et al., 1999; Juliana et al., 2019). Grain yield and agronomic traits were significantly affected by genotype, environment, and genotype-by-environment interactions, which mainly influenced the genetic gain achieved by phenotypic selection. Change in the related performance of lines across environments further

67 complicates selection. Understanding the effects of genetic and genotype-by-environment

68 interaction on yield-related traits can enhance yield improvement during cultivar development 69 (Dhungana et al., 2007; Xing \& Zhang, 2010). With the utilization of multi-environment trials 70 and a high-density genetic map covering all chromosomes, QTL mapping has enabled the 71 dissection of complicated traits like grain yield into individual loci, as well as the ability to 72 quantify epistasis effects among different loci and QTL-by-environment interactions (Doerge, 73 2002). Validated diagnostic markers associated with targeted QTL can be used in marker74 assisted selection. Particularly, breeder-friendly markers linked to QTL associated with 75 agronomic traits will allow breeders to understand the genetic architecture of germplasms, target 76 interested gene loci, and assign heterotic pools in hybrid wheat breeding programs (Adhikari et 77 al., 2020a; Adhikari et al., 2020b).

78 In the current research, grain yield and important agronomic traits of 124 recombinant 79 inbred lines (RILs) derived from two most widely grown hard red winter wheat cultivars in the 80 Southern Great Plains were characterized in multi-environment trials. Linkage and QTL analyses 
81 were conducted to identify genomic regions controlling grain yield and related agronomic traits.

82 The complex genetic basis of four traits was dissected and interpreted.

83

84 Materials \& Methods

85 Plant materials, field trials and phenotyping

86 A population of $124 \mathrm{~F}_{5: 7}$ RILs derived from the cross 'TAM 112'/'TAM 111' was used to map 87 grain yield and related agronomic traits. Both TAM 111 and TAM 112 were developed by Texas 88 A\&M AgriLife Research (Lazar et al., 2004; Rudd et al., 2014) and well-adapted hard red winter 89 wheat (HRWW) cultivars in the Southern Great Plains of the United States. TAM 112 showed 90 better adaption to low input environments, whereas TAM 111 typically produced higher yield in 91 moderate to high input environments. The RILs along with the two parents were planted in five 92 locations including Bushland, TX $\left(35^{\circ} 06^{\prime} \mathrm{N}, 102^{\circ} 27^{\prime} \mathrm{W}\right)$, Chillicothe, $\operatorname{TX}\left(34^{\circ} 15^{\prime} \mathrm{N}, 99^{\circ} 30^{\prime}\right.$ $93 \mathrm{~W})$, Clovis, NM (34 $\left.24^{\prime} \mathrm{N}, 103^{\circ} 12^{\prime} \mathrm{W}\right)$, Etter, TX $\left(35^{\circ} 51^{\prime} \mathrm{N}, 101^{\circ} 58^{\prime} \mathrm{W}\right)$, and Uvalde, TX $94\left(29^{\circ} 21^{\prime} \mathrm{N}, 9^{\circ} 75^{\prime} \mathrm{W}\right)$ during five years (2011 to 2014, and 2017) (Table 1). Yield data were 95 collected from 28 year-location-management combinations (environments) which included 96 Bushland dryland (BD) in 2011 (11BD), 2012 (12BD) and 2017 (17BD), Bushland irrigated (BI) 97 in $2017(17 \mathrm{BI})$, Chillicothe dryland $(\mathrm{CH})$ in $2011(11 \mathrm{CH}), 2012(12 \mathrm{CH})$, and $2014(14 \mathrm{CH})$, 98 Clovis irrigated (CVI) in 2017 (17CVI), Etter with linear irrigation in 2017 (17EI), and various 99 irrigation levels in Etter and Uvalde. Etter with five irrigation levels as $40 \%$ of 100 evapotranspiration (ET) demand (EP1), 50\% of ET demand (EP2), 65\% of ET demand (EP3), $10175 \%$ of ET demand (EP4), 100\% of ET demand (EP5) during 2011 - 2014 included 14 102 environments (11EP1, 11EP2, 11EP3, 11EP4, 11EP5, 12EP1, 12EP2, 12EP3, 13EP2, 13EP3, 103 13EP4, 13EP5, 14EP4, and 14EP5). Uvalde included dryland (UVD) and Uvalde at three 104 irrigation levels (UVL) at 50\% (UV5), 70\% (UV7), and 100\% of ET demand in 2012 and 2013 
105 (12UVD, 12UV5, 12UV7, 12UVL, and 13UVL). Overall, sixteen environments (11BD, 12BD, 106 17BD, 11CH, 12CH, 14CH, 11EP1, 11EP2, 11EP3, 12EP1, 12EP2, 12EP3, 13EP2, 13EP3, 107 12UVD, and 12UV5) were considered as dryland condition and twelve others (17BI, 17CVI, 108 11EP4, 11EP5, 13EP4, 13EP5, 14EP4, 14EP5, 17EI, 12UV7, 12UVL, and 13UVL) were 109 considered as irrigated conditions. All trials were replicated twice in an alpha-lattice design with 110 an incomplete block size of five plots and each parent occurring three times in each replication. 111 The plot dimension was $6.09 \mathrm{~m} \times 1.52 \mathrm{~m}$ in the dryland environments and $4.57 \mathrm{~m} \times 1.52 \mathrm{~m}$ in 112 the irrigated ones with a $0.3-\mathrm{m}$ space between plots. Standard agronomic practices were 113 performed in each trial (Dhakal et al., 2021; Yang et al., 2020b).

114 All 28 environments were harvested using a combine harvester and the total plot weight 115 was used to calculate grain yield (YLD). Traits of test weight (TW), heading date (HD), and 116 plant height (HT) were measured in a subset of environments. TW was measured using Seedburo 117 equipment (www.seedburo.com, Des Plaines, IL, USA) from 19 environments (11BD, 17BD, 118 17BI, 12CH, 14CH, 11EP5, 12EP1, 12EP2, 12EP3, 13EP2, 13EP3, 13EP4, 13EP5, 14EP4, 119 14EP5, 17EP5, 12UV5, 12UV7, and 12UVL). HD was recorded at Feekes growth stage 10.1 120 when half of the plants were fully visible on heads from 11 environments (11BD, 12BD, 17BD, 121 11EP1, 11EP2, 11EP3, 11EP4, 11EP5, 12EP1, 12EP2, and 12EP3). Plant height was measured 122 in centimeters $(\mathrm{cm})$ from representative plants in each plot as the distance from the base of the 123 stem to the top of the spike excluding awns at maturity in 11 environments (11BD, 12BD, 17BD, 124 12CH, 17CVI, 11EP1, 11EP2, 11EP3, 11EP4, 11EP5, and 17EI). 
126

127

128

129

130

131

132

133

134

135

136

137

138

139

140

141

142

143

144

145

\section{Statistical analysis}

Descriptive statistics were calculated using PROC UNIVARIATE in SAS 9.4 (SAS Institue Inc, 2015). The histograms of the residuals for all traits were approximately normal. Best linear unbiased prediction (BLUP) means of lines were calculated for the agronomic traits from the individual environment (IE) as well as multi-environment trials (MET). BLUP was calculated using a restricted maximum likelihood (REML) approach implemented in the 'lme4' package through META-R (Alvarado et al., 2018). The analysis of variance (ANOVA) for IE followed a linear statistical model of individual environment analysis with replication and incomplete block as random effects, while for MET linear statistical model of combined environment analysis was run using PROC MIXED in SAS 9.4 with the environment, replication and incomplete block as random effects. The entry-mean heritabilities, pearson's correlations, biplot analyses, megaenvironments classifications followed the same procedures (Dhakal et al., 2021).

\section{Genotyping and linkage map construction}

DNA extraction, Illumina Infinium iSelect 90K array SNP genotyping and Genome Studio clustering followed the procedures described in the literature (Assanga et al., 2017; Dhakal et al., 2018; Liu et al., 2016; Yang et al., 2019). This population was also genotyped with double digest restriction-site associated DNA sequencing (ddRADSeq) method developed by Peterson et al. (2012) on an Illumina HiSeq 2500 platform $(2 \times 125$ bp paired-end $)$ following the standard procedures (Yang et al., 2020b). JoinMap v4.0 software (Van Ooijen, 2006) was used to 
146 construct the genetic maps using the standard procedures (Dhakal et al., 2021; Yang et al.,

147 2020b). The SNP sequences were listed in supplementary Table S1.

148

149 QTL analysis

150 The additive effects, epistasis, additive-by-environment, and epistasis-by-environment

151 interactions were analyzed using the integrated composite interval mapping (ICIM) function

152 implemented in QTL IciMapping software (Meng et al., 2015). The threshold for declaring a

153 QTL was determined through a permutation test $(\mathrm{n}=1000)$ for a single environment to obtain a

1540.05 genome-wide probability level of Type I error. QTL analyses were run for individual

155 environment (IE) for additive effects (ADD), multiple environment (EPI), and within and across

156 MEs following the standard procedures (Dhakal et al., 2021). QTL designation followed

157 McIntosh et al. (2003) guidelines with a slight change using the format Qtrait.tamu.chrom.Mb,

158 where trait represents a trait name, tamu indicates Texas A\&M University, chrom means the

159 chromosome harboring the QTL, and $M b$ indicates the Mega base pair (Mb) position of the peak

160 SNP within a QTL according to sequence alignment using the IWGSC RefSeq v1.0 reference

161 genome (International Wheat Genome Sequencing Consortium, 2014).

162

163 Results

164 Phenotypic variability, heritability, correlations, and mega-environments

165 Each environment was unique and different from the others across years. In general, Chillicothe

166 and Uvalde, TX were warmer and Etter, TX located in the northern Texas High Plains tends to

167 be cooler. Bushland received below average rainfall in 2011 and almost double in 2012 and

168 2017; however, the rainfalls during the wheat growing seasons were low during 2011-2014, 
169 which were all considered drought years for wheat (Table 1). Temperature was within the

170 optimum range required for winter wheat growth. Combined ANOVA showed highly significant

171 genotype differences $(p<0.001)$ among RILs for all the traits $(p<0.01)$ (Table 2$)$. All the traits

172 were highly heritable $(0.77-0.96)$. Means for YLD, TW, HD, and HT were $287.7 \mathrm{~g} \mathrm{~m}^{-2}, 760.6 \mathrm{~kg}$

$173 \mathrm{~m}^{-3}, 115.5$ Julian days, and $73.8 \mathrm{~cm}$, respectively. Transgressive segregation was observed for all

174 the traits. Based on the means across all environments, TAM 112 had higher yield while TAM

175111 had higher TW, HD and HT based on the overall BLUP means from all tested environments.

176 However, the two parents did not differ significantly for all traits (Table 2).

177 The phenotypic relationships between grain yield and agronomic traits in individual

178 environment was determined using Pearson's correlation coefficients (Table S2). In general,

179 negative correlations were found between HD and YLD in the dryland environments with high

180 correlation values at some dryland environments. Most correlations between YLD and HT were

181 positive and significant in the dryland environments, especially in 2011. Most correlations

182 between YLD and TW were positive and significant except for a few dryland environments. HD

183 and HT were significantly and negatively correlated in dryland environments except for 17BD as

1842017 was a high rainfall year while they were positively correlated in highly irrigated

185 environments. TW had negative correlations with HD while it had positive correlations with HT

186 in dryland environments but negatively correlated in irrigated environments with limited amount 187 of data (Table S2).

189 Boxplot and biplot analysis

190 Heading date was later for the year 2011 except the 11BD environment. Earlier HD was seen in 191 11BD, 12BD, and 17BD (Fig. S1). Plant height was severely affected by drought, as shown in 
192 the Bushland dryland and less affected under irrigated environments in Etter. Plant height was

193 less affected by the year with high rainfall such as 2017. Plants were taller in irrigated and higher

194 rainfall environments (17CVI and 17EI), almost three times taller in these optimum

195 environments. Test weight was also affected by drought. The lowest TW was observed in 12EP1

196 and 12EP3, while the highest TW was in 17BI. Grain yield was lowest in the driest year and dry

197 environments. However, the top 20 high yielding lines across individual environments were

198 distributed within the 106 lines out of 124 lines (Table S3), showing the strong genotype-by-

199 environment interactions and the necessary for mega-environement classification.

200 Mega-environment analysis categorized all the environments into two or four different

201 mega-environments for different traits (Fig. 1). Grain yield had ME1 (11CH, 14EP4, 14EP5,

202 17BI, and 17CVI), ME2 (11BD, 11EP5, 12BD, 12EP1, 12EP2, and 17EI), ME3 (12CH, 12UVD,

203 13UVL, and 17BD), and ME4 (12UV5, 12UV7, 12UVL, and 14CH); Test weight had ME1

204 (12BD, 12EP2, 12UV7, 12UVL, 12UV5, 13EP3, and 14CH) and ME2 (11EP5, 12CH, 12EP1,

205 12EP3, 13EP2, 13EP4, 13EP5, 14EP4, 14EP5, 17BD, 17BI, and 17EI). Plant height had ME1

206 (11EP3, 11BD, 12BD, 17CVI, and 12CH) and ME2 (11EP1, 11EP2, 11EP4, 11EP5, 17BD, and

207 17EI). Heading date had ME1 (12EP2, 11EP4, 11BD, 12EP1, and 17BD) and ME2 (12EP3,

208 12BD, 11EP5, 11EP1, and 11EP3). 11EP2 was excluded since it was far deviated from the rest

209 (Fig. 1). QTL was analyzed within and across ME's for yield and test weight.

210

211 Linkage Map and QTL analyses

212 We used JoinMap 4.0 and QTL ICIMapping 4.2 to construct genetic maps and QTL analyses

213 following similar procedures as Yang et al. (2019). 
agronomic traits across 28 environments over five years was identified through the analyses of

associated with a single trait from at least two out of IE, MET, ME analyses (Table 3, Fig. 2, Fig.

S2, and S3). These consistent QTL were identified for all the four traits analyzed on 15

chromosomes including 1A, 1D, 2B, 2D, 3B, 3D, 4B, 4D, 5A, 5B, 6A, 6B, 6D, 7B, and 7D.

220

221

\section{Grain Yield}

222

A total of 18 QTL for YLD were detected. Nine common consistent and pleiotropic QTL were

223

located on chromosomes 1D, 4B, 4D, 6A, 7B, and 7D. The other nine consistent QTL were mapped on chromosomes 1A, 3B, 4B, 4D, and 7D (Table 3, Table S4, and Fig. 2). Favorable

alleles from TAM 111 for QTL on the chromosomes 1A (411.7 and 585.6 Mb), 3B (48.6 Mb),

4B (226.8 Mb), 4D (445.5 Mb), 6A (12.4 and 608.5 Mb), 7B (15.6 Mb), and 7D (84.3 Mb)

227

explained up to $41.3 \%$ of total phenotypic variations and increased yield by up to $37.41 \mathrm{~g} \mathrm{~m}^{-2}$

228

from Qyld.tamu.4B.267 in 17CVI while the remaining QTL with favorable alleles from TAM

112 increased yield by up to $13.54 \mathrm{~g} \mathrm{~m}^{-2}$ and explained a total of $25 \%$ of yield variations at ME3 including 12CH, 12UVD, 13UVL, and 17BD from Qyld.tamu.1A.587 (Table 3, Table S4, and Fig. S3). Favorable allele switched between two parents for QTL on the chromosome 4B at 266.8 $\mathrm{Mb}$ and 4D at 445.5 Mb. TAM 111 favorable allele of Qyld.tamu.4B.267 increased yield by $37.41 \mathrm{~g} \mathrm{~m}^{-2}$ in $17 \mathrm{CVI}$ and increased yield by $3.38 \mathrm{~g} \mathrm{~m}^{-2}$ across $\mathrm{ME} 1$, including $11 \mathrm{CH}, 14 \mathrm{EP} 4$, 14EP5, 17BI, and 17CVI while TAM 112 allele only increased yield by $0.42 \mathrm{~g} \mathrm{~m}^{-2}$ when analyzed across all 28 environments. However, additive-by-environment contributed very large part of PVE. The additive-by-17CVI interaction explained $63.3 \%$ out of the total $63.5 \% \mathrm{PVE}$ 
237 (Table S4). The QTL Qyld.tamu.4D.446 had favorable alleles from TAM 111 that increased 238 yield by 8.59 and $3.98 \mathrm{~g} \mathrm{~m}^{-2}$ when analyzed for individual environment in $14 \mathrm{CH}$ and across $239 \mathrm{ME} 4$, including 12UV5, 12UV7, 12UVL, and 14CH while it had favorable allele from TAM 112 240 that increased yield by $0.47 \mathrm{~g} \mathrm{~m}^{-2}$ when analyzed across all 28 environments (Table 3, Table S4). Among the major consistent QTL for yield, those QTL that had larger additive effect

242 contributions from across environment analyses are of interest to breeders for yield 243 improvement. Two QTL, Qyld.tamu.1A.587 and Qyld.tamu.7D.61, increased yield by 4.43 and $2446.57 \mathrm{~g} \mathrm{~m}^{-2}$ with TAM 112 allele contributing $14.6 \%$ and $13.3 \%$ additive effect for percentage of 245 variations explained (PVE) across the four mega-environments and ME3 (including 12CH, 246 12UVD, 13UVL, and 17BD) analyses, respectively (Table S4). A third QTL at $659.2 \mathrm{Mb}$ on 4B 247 increased yield by $6.43 \mathrm{~g} \mathrm{~m}^{-2}$ with TAM 112 allele contributing $4.9 \%$ additive PVE. A set of four 248 additional QTL, at 20.6 and $109.8 \mathrm{Mb}$ on $4 \mathrm{D}, 15.6 \mathrm{Mb}$ on 7B, and $84.3 \mathrm{Mb}$ on 7D, increased 249 yield by 2.55 to $8.16 \mathrm{~g} \mathrm{~m}^{-2}$ with TAM 111 alleles contributing additive PVE ranging from $4.9 \%$ 250 to $7.9 \%$. These seven yield QTL will be our focus for further application. The additive-by-environment interaction increased yield by up to $37.83 \mathrm{~g} \mathrm{~m}^{-2}$ from 252 Qyld.tamu.4B.267 under 17CVI with TAM 111 allele while the same QTL had favorable allele 253 from TAM 112 that only increased $11.13 \mathrm{~g} \mathrm{~m}^{-2}$ from interaction under 17BI when it was 254 analyzed for across all 28 environments. Furthermore, the same QTL had interactional effect that 255 increased yield by $34.03 \mathrm{~g} \mathrm{~m}^{-2}$ under 17CVI with TAM 111 allele and increased yield by $14.92 \mathrm{~g}$ $256 \mathrm{~m}^{-2}$ under 17BI with TAM 112 allele from analyses of across ME1 including 11CH, 14EP4, 257 14EP5, 17BI, and 17CVI. Similarly, Qyld.tamu.7D.84 had interactional effect increased yield by $25820.3 \mathrm{~g} \mathrm{~m}^{-2}$ under 17BI with TAM 111 allele and increased by $11.12 \mathrm{~g} \mathrm{~m}^{-2}$ under $12 \mathrm{UV} 5$ with 259 TAM 112 allele when analyzed across all 28 environments. The same QTL had an interactional 
260 effect of increasing yield by $13.53 \mathrm{~g} \mathrm{~m}^{-2}$ with TAM 111 allele under 17BI when it was analyzed 261 across ME1 including 11CH, 14EP4, 14EP5, 17BI, and 17CVI.

262 Five major QTL had QTL-by-environment interactions from TAM 111 alleles.

263 Qyld.tamu.3B.49 increased yield by $10.8 \mathrm{~g} \mathrm{~m}^{-2}$ under $12 \mathrm{UVL}$ when it was analyzed across ME4 264 including 12UV5, 12UV7, 12UVL, and 14CH. The effect of increasing yield by 11.01 and 26.24 $265 \mathrm{~g} \mathrm{~m}^{-2}$ were observed when all 28 environments were analyzed for QTL Qyld.tamu. 4 D. 446 under 266 11EP4, and Qyld.tamu.4D.110 under 17BI, respectively. The two QTL, Qyld.tamu.7D.84 and 267 Qyld.tamu.4D.110 had interactional effect of increasing yield by 13.53 and $19.75 \mathrm{~g} \mathrm{~m}^{-2}$ with 268 TAM 111 allele under 17BI from across ME1 analyses (Table S4).

269

270 Test Weight

271 A total of 32 unique QTL for test weight were identified. Six consistent and pleiotropic QTL 272 were mapped on chromosomes $1 \mathrm{~A}$ at $11.8 \mathrm{Mb}, 1 \mathrm{D}$ at $421.8 \mathrm{Mb}, 4 \mathrm{D}$ at $109.8 \mathrm{Mb}, 6 \mathrm{~A}$ at $12.4 \mathrm{Mb}$ 273 and $608.5 \mathrm{Mb}$, and 7D at $60.6 \mathrm{Mb}$. Additional 26 consistent QTL were located on 14 274 chromosomes (Tables 3, Fig. 2, and Fig. S2). The favorable alleles for TW were from TAM 111 275 on chromosome $1 \mathrm{~A}$ at $11.8,380.7$, and $485.2 \mathrm{Mb}, 3 \mathrm{~B}$ at $507.0 \mathrm{Mb}, 3 \mathrm{D}$ at $548.6,554.7$, and 562.7 $276 \mathrm{Mb}, 5 \mathrm{~B}$ at 589.4 and $646.0 \mathrm{Mb}, 6 \mathrm{~A}$ at $603.3,608.5$ and $611.6 \mathrm{Mb}, 6 \mathrm{D}$ at $459.2 \mathrm{Mb}, 7 \mathrm{~B}$ at 8.5 and $27764.5 \mathrm{Mb}$, and 7D at $604 \mathrm{Mb}$ that explained up to $11.3 \%$ phenotypic variation and increased TW 278 by $7.23 \mathrm{~kg} \mathrm{~m}^{-3}$ with Qtw.tamu.6D.459 in 12UV5 (Table 3, Table S4). The rest of the QTL had 279 favorable allele from TAM 112 that increased TW by up to $10.35 \mathrm{~kg} \mathrm{~m}^{-3}$ with Qtw.tamu. 4 D. 63 in 280 13EP2. The QTL on the chromosome $6 \mathrm{~A}$ at $603.3 \mathrm{Mb}$ received favorable alleles from both 281 parents depending on the particular environments. Qtw.tamu.6A.603 explained up to $21.4 \%$ of 282 the phenotypic variation and increased TW by $16.58 \mathrm{~kg} \mathrm{~m}^{-3}$ with alleles from TAM 112 in 
283 12UV7 but it only increased $0.08 \mathrm{~kg} \mathrm{~m}^{-3}$ with TAM 111 allele in the analyses across all 19 284 environments.

285 Based on PVE of additive effects, only Qtw.tamu.1D.422 along with other four QTL on $2864 \mathrm{D}$ at $109.8 \mathrm{Mb}, 6 \mathrm{~A}$ at $12.4 \mathrm{Mb}$, and on $6 \mathrm{~B}$ at 466.0 and $559.4 \mathrm{Mb}$, had values ranging from $2873.8 \%$ to $10.2 \%$ with TAM 112 alleles that increased test weight by 2.26 to $3.47 \mathrm{~kg} \mathrm{~m}^{-3}$ (Table 288 S4). One QTL Qtw.tamu.6D.459 increased test weight by $3.66 \mathrm{Kg} \mathrm{m}^{-3}$ with TAM 111 allele. 289 For the QTL-by-environmental interactions based on across all individual environment 290 and across ME2 analyses, Qtw.tamu.4D.63 had additive effects of 7.34 and $7.05 \mathrm{~kg} \mathrm{~m}^{-3}$ in 291 environment 13EP2, respectively while their QTL additive effects only increased 2.89 and 3.18 $292 \mathrm{~kg} / \mathrm{m} 3$ (Table S4). Qtw.tamu.6A.603 had interactional effect of increasing TW by 16.65 and $29315.14 \mathrm{~kg} \mathrm{~m}^{-3}$ under the environment $12 \mathrm{UV7}$ from the analyses of across all environments and 294 ME1, respectively (Tables S2). All these favorable alleles were from TAM 112. 295

\section{Pleiotropic QTL to grain yield and test weight}

297 From the multiple trait QTL analyses, nine unique consistent QTL regions for grain yield are 298 also linked to agronomic traits (Table 3, Table S4, and Fig. 2). They were detected on 299 chromosome 1A, 1D, 4B, 4D, 6A, 7B, and 7D. QTL linked to HD and TW on chromosomes 1A 300 at $11.8 \mathrm{Mb}$ increased HD by 0.28 day with TAM 112 allele while the TAM 111 alleles increased 301 TW by $1.87 \mathrm{~kg} \mathrm{~m}^{-3}$ (Table 3, Table S4). QTL on 1D at $421.8 \mathrm{Mb}$ had a favorable allele from 302 TAM 112 that increased TW by $6.41 \mathrm{~kg} \mathrm{~m}^{-3}$ and YLD by $6.87 \mathrm{~g} \mathrm{~m}^{-2}$. QTL on chromosome 4B at $303659.2 \mathrm{Mb}$ was associated with HD and YLD. Allele from TAM 112 increased HD by 1.53 days 304 and YLD by $9.88 \mathrm{~g} \mathrm{~m}^{-2}$. Plant height and YLD were associated with QTL on chromosome 4D at $30520.6 \mathrm{Mb}$. TAM 112 allele increased HT by $0.47 \mathrm{~cm}$ under combined DRY while TAM 111 allele 
306 increased YLD by $17.32 \mathrm{~g} \mathrm{~m}^{-2}$ under 17CVI. Another QTL on chromosome 4D at 109.8 Mb was 307 associated with TW and YLD. TAM 112 allele increased TW by up to $8.01 \mathrm{~kg} \mathrm{~m}^{-3}$ in $13 \mathrm{EP} 3$

308 while TAM 111 allele increased YLD by $28.06 \mathrm{~g} \mathrm{~m}^{-2}$ under 17BI. The two QTL on chromosome $3096 \mathrm{~A}$ at $12.4 \mathrm{Mb}$ and $608.5 \mathrm{Mb}$ were associated with both TW and YLD. TAM 112 allele of QTL 310 at $12.4 \mathrm{Mb}$ increased TW by $3.58 \mathrm{~kg} \mathrm{~m}^{-3}$ while TAM 111 allele increased YLD by $19.58 \mathrm{~g} \mathrm{~m}^{-2}$. 311 For the QTL at $608.5 \mathrm{Mb}$, TAM 111 allele increased TW by $5.19 \mathrm{~kg} \mathrm{~m}^{-3}$ under 13EP5 and YLD 312 by $3.18 \mathrm{~g} \mathrm{~m}^{-2}$ under ME3. Heading date and YLD were co-located on chromosome 7B at 15.6 $313 \mathrm{Mb}$. TAM 112 allele increased HD by 0.25 day while TAM 111 allele increased YLD by up to $3147.23 \mathrm{~g} \mathrm{~m}^{-2}$ under 12CH. QTL on chromosome 7D at $60.6 \mathrm{Mb}$ was associated with HT, TW, and 315 YLD. The favorable allele from TAM 111 increased HT by $1.05 \mathrm{~cm}$ under 17EI while the 316 favorable allele from TAM 112 increased TW and YLD by up to $8.48 \mathrm{~kg} \mathrm{~m}^{-3}$ under $11 \mathrm{EP} 5$ and $3178.73 \mathrm{~g} \mathrm{~m}^{-2}$ under 12UVD, respectively. Another QTL on chromosome 7D at $64.3 \mathrm{Mb}$ was 318 associated with HT and yield. TAM 111 allele increased HT by $1.63 \mathrm{~cm}$ under 11EP5 and TAM 319112 allele increased yield by $6.45 \mathrm{~g} \mathrm{~m}^{-2}$ under $12 \mathrm{CH}$. Among the five pleiotropic QTL associated 320 with both TW and yield, the two QTL on 1D and 7D have favorable alleles increasing both traits 321 from TAM 112 while the QTL on 4D at 109.8 and 6A at $12.4 \mathrm{Mb}$ had TAM 112 allele for TW 322 and TAM 111 allele for yield. The QTL on 6A at 608.5 Mb had TAM 111 allele increasing both 323 traits (Table 3, Table S4).

324

Interactions of epistasis, epistasis-by-environment, and additive-by-environment

326 There were 359 interactions of additive-by-additive, additive-by-environment, and epistasis-by327 environment with a total LOD $\geq 12$ for all traits (Table S5, Fig. S4). Only 139 out of 359 328 interactions had $\operatorname{LOD}(\mathrm{AA})>10.0$. There were only two interactions for HD, one for yield, and 
329 the rest of the 136 for TW. None of the interactions was the same as any of those major

330 consistent and pleiotropic QTL for heading date and yield while there were five major consistent

331 QTL associated with the epistasis interactions for TW (Table S5). They were a marker linked to

332 Qtw.tamu.5A.702 interacting with two other markers on $1 \mathrm{~A}$ at $465.5 \mathrm{Mb}$ and on $5 \mathrm{~A}$ at $584.4 \mathrm{Mb}$,

333 a marker linked to Qtw.tamu.5B.646 interacting with IWB5813 on $2 \mathrm{~B}$ at $25.2 \mathrm{Mb}$, a marker

334 linked to Qtw.tamu.6A.12 interacting with a marker on 1B at $466 \mathrm{Mb}$, IWB38972 linked to

335 Qtw.tamu.6B.130 interacting with a marker on 1A at $544.6 \mathrm{Mb}$, IWB6455 linked to

336 Qtw.tamu.7B.9 interacting with a marker on 1D at $418.5 \mathrm{Mb}$. However, they only explained TW

337 variations by $1.3 \%$ to $2.8 \%$ with additive effects from epistasis less than $0.25 \mathrm{~kg} \mathrm{~m}^{-3}$.

338 Furthermore, neither of any interactions from epistasis, the interactions between either marker

339 from the epistasis with the environment, or the epistasis-by-environment interactions had effects 340 that increased TW by more than $1 \mathrm{~kg} \mathrm{~m}^{-3}$.

341 For the interaction of yield between a marker on $5 \mathrm{~B}$ at $655.5 \mathrm{Mb}$ and a marker on $7 \mathrm{~B}$ at

$342740.1 \mathrm{Mb}$, its epistasis increased yield by $33.74 \mathrm{~g} \mathrm{~m}^{-2}$. The marker on $5 \mathrm{~B}$ at $655.5 \mathrm{Mb}$ increased

343 yield by more than $30 \mathrm{~g} \mathrm{~m}^{-2}$ with TAM 111 allele under drier environments $11 \mathrm{CH}, 12 \mathrm{EP} 3$, and

344 12UV5, and with TAM 112 allele under higher irrigated environments 11EP5, 12UV7, and

345 17BI. The marker on 7B at $740.1 \mathrm{Mb}$ increased yield by more than $30 \mathrm{~g} \mathrm{~m}^{-2}$ with TAM 111

346 alleles under environments 11EP5, 12UV5, and 13UVL, and with TAM 112 alleles under

347 environments $12 \mathrm{CH}$ and 17EI. The epistasis-by-environment interaction effects increased yield

348 by more than $30 \mathrm{~g} \mathrm{~m}^{-2}$ with TAM 111 alleles under less irrigated environments 11EP2, 12UV7,

349 13EP2, and 13EP3, but with TAM 112 alleles under highly irrigated environments 11EP3,

350 11EP4, 11EP5, 17BI and 17CVI (Table S5). Neither marker regions were involved with major

351 QTL for yield. 

interactions for HT, 53 interactions for TW, and 153 interactions for yield. For TW, there were

354 five interactions that increased TW by more than $0.3 \mathrm{~kg} \mathrm{~m}^{-3}$ with TAM 111 alleles and 14

355 interactions with TAM 112 alleles but all of them had effect less than $0.5 \mathrm{~kg} \mathrm{~m}^{-3}$. One major QTL Qtw.tamu.4D.63_interacting with 12EP1, 12EP3, 17BD increased TW by $0.38-0.44$ kg $\mathrm{m}^{-3}$ with TAM 112 allele while the other two major QTL Qtw.tamu.2D.487 and Qtw.tamu.7B.9 had interactional effects less than $0.3 \mathrm{~kg} \mathrm{~m}^{-3}$ (Table S4).

For yield, a total of 1,092 interactions increased yield by more than $50 \mathrm{~g} \mathrm{~m}^{-2}$ based on the 153 pairs of QTL across 28 environments with 513 from TAM 112 alleles and 579 from TAM 111 alleles. A subset of 87 interactions increased yield by more than $100 \mathrm{~g} \mathrm{~m}^{-2}$. At the first locus of the epistasis, environments 11EP4, 11EP5, 12UV5, and 17BI interacted with a set of 40, 55, 43, and 41 markers increased YLD more than $50 \mathrm{~g} \mathrm{~m}^{-2}$ while the corresponding subsets of four, three, three, and one marker increased yield by more than $100 \mathrm{~g} \mathrm{~m}^{-2}$. At the second locus, environments 11EP4, 11EP5, 12UV7, 12UVL, 17BI interacted with a set of 35, 40, 29, 17, and 23 markers increased yield by more than $50 \mathrm{~g} \mathrm{~m}^{-2}$ while the corresponding subsets of one, five, two, three, and two markers increased yield by more than $100 \mathrm{~g} \mathrm{~m}^{-2}$. For epistasis-byenvironment interactions, environments 11EP3, 11EP4, 11EP5, 12UV5, 12UV7, 12UVL, 17BI, and $17 \mathrm{CVI}$ interacted with a set of $38,52,55,75,46,45,75$, and 29 epistasis increased yield by more than $50 \mathrm{~g} \mathrm{~m}^{-2}$ while the corresponding subset of four, seven, 14, 14, two, three, 18, and one marker increased yield by more than $100 \mathrm{~g} \mathrm{~m}^{-2}$ with three interactions. The top four marker pairs increased yield by more than $100 \mathrm{~g} \mathrm{~m}^{-2}$ with additive-by-environment or epistasis-byenvironment interactions. A marker on $6 \mathrm{~A}$ at $613.8 \mathrm{Mb}$ interacted with $12 \mathrm{UV} 5$ increased yield by $127.2 \mathrm{~g} \mathrm{~m}^{-2}$ with TAM 111 allele. The epistasis between $6 \mathrm{~A}$ marker with a marker on 7D at 
$375585.6 \mathrm{Mb}$ increased yield by $105.7 \mathrm{~g} \mathrm{~m}^{-2}$ under 12UV5 with TAM 112 allele while it increased

376 yield by $106.2 \mathrm{~g} \mathrm{~m}^{-2}$ under $11 \mathrm{EP} 4$ with TAM 111 alleles. The $2^{\text {nd }}$ set of three interactions were as

377 follow: a marker on $4 \mathrm{~A}$ at $378.3 \mathrm{Mb}$ and IWA5751 on 4D at $408.8 \mathrm{Mb}$ interacted with 11EP4

378 increased yield by $104.19 \mathrm{~g} \mathrm{~m}^{-2}$ with TAM 112 allele and by $110.72 \mathrm{~g} \mathrm{~m}^{-2}$ with TAM 111 allele,

379 respectively; the epistasis between these two markers interacted with 12UV5 increased yield by

$380102.07 \mathrm{~g} \mathrm{~m}^{-2}$ with TAM 111 allele. The $3^{\text {rd }}$ set of three interactions were: marker IWB52359 on

$3817 \mathrm{D}$ at $40.1 \mathrm{Mb}$ interacted with 12UVL and 12UV7 increased yield by 128.98 and $109.82 \mathrm{~g} \mathrm{~m}^{-2}$

382 with TAM 112 allele, respectively; its epistasis with a marker on 7B at $6.8 \mathrm{Mb}$ interacting with

383 17BI increased yield by $146.04 \mathrm{~g} \mathrm{~m}^{-2}$ with TAM 111 allele. The fourth set of three interactions

384 were all epistasis-by-environment effects between IWB73713 on 1B at $675.6 \mathrm{Mb}$ and IWA1924

385 on $6 \mathrm{D}$ at $461.4 \mathrm{Mb}$ that increased yield by $105.73,106.52$, and $106.25 \mathrm{~g} \mathrm{~m}^{-2}$, respectively, under

386 11EP5, 12UV5, and 12UVL with the first interactional allele from TAM 111 and the rest two

387 from TAM 112 (Table S5). The highest effect from TAM 111 allele increased yield by $184.15 \mathrm{~g}$

$388 \mathrm{~m}^{-2}$ that was from a major QTL Qyld.tamu.6A.12 under 17BI while the highest effect from TAM

389112 alleles increased yield by $155.18 \mathrm{~g} \mathrm{~m}^{-2}$ was from epistasis-by-environment effect between

390 IWA4746 on 2D at $14.4 \mathrm{Mb}$ and a marker on $3 \mathrm{~A}$ at $7.6 \mathrm{Mb}$ under 11EP5. Two other major QTL,

391 Qyld.tamu.4D.21 and Qyld.tamu.4B.659, were involved with epistasis-by-environment

392 interactions but most interactional effect only increased yield by less than $100 \mathrm{~g} \mathrm{~m}^{-2}$ (Table S5)

393

394 Discussion

395 Highly heritable traits are important to breeders. The yield and agronomic traits analyzed in this

396 study were moderate to highly heritable (Table 2). The genotypic variances were larger than the

397 genotype-by-environment and residual variance for HD and TW. Higher heritability indicated 
398 that these traits were largely genetically controlled, making them suitable for genetic gain from 399 selection in a breeding program. Higher heritability in yield and agronomic traits have been 400 reported by Zhang et al. (2018). Since yield is controlled by many genes with each showed 401 minor effects and is easily influenced by the environment, it was unusual to see high heritability 402 for yield approach 0.7 (Li et al., 2007). However, highly significant $\mathrm{G} \times \mathrm{E}$ interactions were 403 found for all the traits. Given all the possible environmental conditions of this study, observing 404 significant environmental and genotype-by-environment interaction variances are expected. This 405 population was planted in a wide range of environments, including diverse soil types, 406 precipitations, and temperatures. Our testing environment included locations with day 407 temperature $>30{ }^{\circ} \mathrm{C}$ in Southern Texas to locations with day temperature $<10{ }^{\circ} \mathrm{C}$ in the High 408 Plains of Texas. These two environmental covariables significantly alter genotype expression 409 across environments in wheat yield (Kuchel et al., 2007; Saini \& Aspinall, 1982). All the dryland 410 experiments in the High Plains of Texas received less than five inches of rainfall during the 411 growing seasons, which is typical in this region. This population suffered an extreme drought in 4122011 and freeze damage in the late growing season in 2013. Globally wheat benefitted from 413 reduced height as that increased harvest index, straw strength, and yield. It is also known that 414 reduced height, accompanied by a higher input level, imparted a significant increase in yield 415 (Borlaug, 1968). Our study indicated that YLD showed positive correlations with HT in dry 416 environments, suggesting that taller plants performed better under dry environments. When 417 accompanied by high temperatures, a severe drought lowers yields in nearly all crops in water418 limited production agriculture (Hossain et al., 2012). However, plants utilize different drought 419 tolerance mechanisms to sustain yield under drought stress. In a dry environment, early maturing 420 cultivars were able to avoid drought and terminal heat stress and maintained a higher yield, as 
421 seen by negative associations between yield and heading date in most drier environments from

422 this study. Also, late-flowering genotypes were disadvantageous under drought since there is less

423 chance of setting florets but a higher chance of being sterile spikelet.

424 In this study, 115 unique QTL were identified on all the chromosomes except 4A and 5D

425 (Table S4). Among them, 51 consistent QTL and 10 pleiotropic QTL were identified. To validate

426 the QTL found in this study, we compared with some phenological development genes and QTL

427 recently published for these traits. Data from a subset of 11 environments in this study were used

428 to map QTL for yield component traits like kernel per spike (KPS), spike $\mathrm{m}^{-2}$ (SPM), and

429 thousand kernel weight (TKW) (Yang et al., 2020b). QTL for end-use quality traits were mapped

430 based on a subset of seven environments (Dhakal et al., 2021). Comparing QTL mapped with the

431 previously published research based on the same population, eight consistent QTL were

432 confirmed for yield including the ones on $1 \mathrm{~A}$ at $411.7 \mathrm{Mb}, 1 \mathrm{D}$ at $421.8,4 \mathrm{~B}$ at $659.2 \mathrm{Mb}$, on 4D

433 at 20.6 and $109.8 \mathrm{Mb}$, on $6 \mathrm{~A}$ at $12.4 \mathrm{Mb}$, on $7 \mathrm{~B}$ at $15.6 \mathrm{Mb}$, and on $7 \mathrm{D}$ at $591.2 \mathrm{Mb}$.

434 Furthermore, a set of seven pleiotropic QTL were identified including the ones on 1A at 485.2

$435 \mathrm{Mb}$ for test weight, midline peak width, and midline right slope; two QTL on $2 \mathrm{D}$ at $16 \mathrm{Mb}$ for

$436 \mathrm{HD}$ and TKW, and at 486.8 Mb for test weight and TKW; three QTL on 4D at 20.6 Mb for

437 biomass yield, yield, and height, at 29.0 $\mathrm{Mb}$ for flour protein, harvest index, and test weight, at

$438109.8 \mathrm{Mb}$ for grain yield, flour yield, flour protein, and test weight; and one QTL on 6D at 459.2

$439 \mathrm{Mb}$ for biomass yield and test weight (Dhakal et al., 2021; Yang et al., 2020b).

440 The QTL on 7D at 64.3 Mb for yield and height is close to a QTL for flour yield linked to

441 Excalibur_c22419_460 on 7D at $67 \mathrm{Mb}$ from RL4452 (Cabral et al., 2018). Compared with

442 those major genes based on the linked SNPs (Rasheed et al., 2016), we found that the QTL on

$4431 \mathrm{D}$ at $421.8 \mathrm{Mb}$ for test weight and yield was about $10 \mathrm{Mb}$ away from the high molecular weight 
444 Glu-Dlb that was located around 412.1 Mb (Dhakal et al., 2021). The QTL for yield on 7D at $445591.2 \mathrm{Mb}$ was very close to the greenbug resistance gene Gb3 and Gb7 (Liu et al., 2014; Tan et 446 al., 2017). Several QTL for test weight identified from this study were very close or overlapped 447 with other published QTL for quality traits. The test weight QTL on 1D at 375.4 Mb was very 448 close to a QTL linked to Kukri_c20062_389 on 1D at 379.5 Mb (Jin et al., 2016). The test 449 weight QTL on 1A at 11.8 Mb was very close to a QTL for midline peak time of dough 450 mixograph linked to RFL_Contig1118_65 at 14.5 Mb and another QTL on 6A at 603.3 Mb was 451 not far away from a QTL for flour protein linked to Excalibur_rep_c69981_75 at 595.6 Mb of 452 two Chinese wheat cultivars (Guo et al., 2020). Four QTL from this study were very close to 453 QTL for quality traits from an association analysis based on nine quality traits (Yang et al., 454 2020a). QTL on $1 \mathrm{~A}$ at 585.6 Mb for yield was very close to a QTL at 584.7 Mb for grain protein, 455 total starch content, and dough development time; QTL for yield on 4B at 659.2-660.9 Mb was 456 very close to two QTL at 651.8 and $660.7 \mathrm{Mb}$ for grain protein, flour yield, test weight, and wet 457 gluten; QTL for test weight and yield on 6A at 603.3 and 608.5 Mb were very close to a QTL at $458602.9 \mathrm{Mb}$ for grain protein, test weight, and total starch content; Compared with QTL found 459 using more than 3,000 lines with more than 50 trait-environment combinations (Juliana et al., 460 2019), three QTL were found at very close physical locations. Yield QTL Qyld.tamu.1A.586 was 461 very close to a QTL at 585.7 Mb for test weight; Qtw.tamu.6B.559 was very close to a QTL at $462552.9 \mathrm{Mb}$ for thousand kernel weight; QTL associated with test weight, heading date, and yield 463 on $7 \mathrm{~B}$ at 8.5 and $15.6 \mathrm{Mb}$ were close to a QTL at $8.4 \mathrm{Mb}$ that was around $V r n-B 3$ gene; QTL for 464 height, test weight and yield on 7D at 60.6 and $64.3 \mathrm{Mb}$ from this study were close to a QTL for 465 maturity time where $V r n-D 3$ was around. We identified Qyld.tamu.1A.587 for YLD with peak 466 marker IWB34513, which is very close to peak marker IWA1644 linked to early flowering gene 
467 Elf3 at $590 \mathrm{Mb}$ (Alvarez et al., 2016; Zhang et al., 2018). Early flowering is a drought escape 468 mechanism adopted by many crop plants to avoid water-deficit stress. In the US Southern High 469 Plains where moderate-to-severe water stress frequently occurs, early flowering would be a 470 helpful strategy to cope with water-deficit stress. Early maturity achieved through early 471 flowering and maturity resulted in positive genetic gains (De Vita et al., 2007). $472 \quad$ Pleiotropic QTL detected from various analyses indicated their reliability. Our results 473 showed that 51 consistent QTL were distributed on 15 chromosomes and 10 of them had 474 pleiotropic effects. QTL for strongly correlated traits were often clustered in the same genomic 475 region. However, in this study, we found QTL for traits with weaker correlations also clustered 476 in some cases. For example, QTL for HD and TW on 1A at $12 \mathrm{Mb}$, and TW and YLD on the 477 long arm of chromosome 1D at $422 \mathrm{Mb}$. Traits with weak or no correlation can be selected with 478 the combinations of various alleles for improving multiple traits. It also avoids the undesirable 479 effect of one QTL by selecting against it while improving another QTL.

The total of 28 environments for yield were categorized into four mega-environments and 19 environments for TW, 11 environments for height and 10 environments for heading date were 482 classified into two mega-environments, respectively based on the biplot analyses (Fig. 1). TAM 483112 alleles increased HD in most QTL while only half of QTL increased height with TAM 112 484 alleles. TW from 16 out of 32 QTL were increased by TAM 112 alleles that were located on 485 chromosomes 1D, 2B, 4D, 5A, and 6B while yield from eight out of 18 QTL was increased by 486 TAM 112 alleles that were on chromosomes 1B, 4B, and 7D (Table 3, Table S4). TAM 112 487 alleles increased both yield and test weight under drier environments while TAM 111 alleles 488 increased both traits under irrigated environments (Table 3, Table S4). Similar findings were 489 observed in a greenhouse study using TAM 111 and TAM 112. TAM 112 was able to yield more 
490 grains than TAM 111 in dry environments due to its superior gas exchange efficiency and other 491 genetic differences in the two cultivars (Chu et al., 2021; Reddy et al., 2014; Thapa et al., 2018).

492 The total PVE was partitioned into PVE due to Additive and additive-by-environment 493 effects, as well as epistasis and epistasis-by-environment interactions; therefore, only those 494 major QTL with larger PVE from additive effects are of interest for further applications while 495 those QTL with larger additive-by-environment and other interactions can be avoided in the 496 future research.

497

498 Conclusions

499 A set of 124 recombinant inbred lines derived from a cross of two popular hard red winter wheat 500 cultivars, TAM 111 and TAM 112, was characterized for yield, test weight, height, and heading 501 date from 28 environments during five growing seasons. All the traits had high heritability with 502 most of the phenotypic variations due to genotypic effects. A total of 115 unique QTL were 503 detected for all the traits with 51 consistent QTL were defined. A set of 10 QTL consistent on 504 chromosomes 1A, 1D, 4B, 4D, 6A, 7B, and 7D had pleiotropic effects. Seven QTL for yield and 505 six QTL for test weight that explained phenotypic variations more than 5\% with major additive 506 effects was worthy of further applications. Allele from TAM 112 were expressed in the dry 507 environments and TAM 111 in the irrigated environments. Only a few major QTL, three for 508 yield, six for test weight, and one for height, were involved in interactional effects. Because of 509 the complex inheritance of these traits, it will be necessary to validate these QTL in different 510 wheat backgrounds evaluated under similar growth conditions before developing markers for 511 marker-assisted selection.

512

513 Acknowledgements 
514 The authors appreciate the technical support from Maria Pilar Fuentealba, Hangjin Yu, and Lisa

515 Garza, and Jaqueline Avila. We thank Shuhao Yu for his review suggestions.

516

517

518

519

520

521

522

523

524

525

526

527

528

529

530

531

532

533

534

535

536

537

538

539

540

541

542

543

544

545

546

547

548

549

550

551

552

553

554

555

556

557

\section{References}

Addisu M, Snape JW, Simmonds JR, and Gooding MJ. 2010. Effects of reduced height (Rht) and photoperiod insensitivity $(\mathrm{Ppd})$ alleles on yield of wheat in contrasting production systems. Euphytica 172:169-181. 10.1007/s10681-009-0025-2

Adhikari A, Ibrahim AMH, Rudd JC, Baenziger PS, Easterly A, Garst N, Belamkar V, and Sarazin J-B. 2020a. Supplementing selection decisions in a hybrid wheat breeding program by using F2 yield as a proxy of F1 performance. Euphytica 216:130. 10.1007/s10681-020-02664-0

Adhikari A, Ibrahim AMH, Rudd JC, Baenziger PS, and Sarazin J-B. 2020b. Estimation of heterosis and combining abilities of U.S. winter wheat germplasm for hybrid development in Texas. Crop Science 60:788-803. 10.1002/csc2.20020

Alvarado G, López M, Vargas M, Pacheco Á, Rodríguez F, Burgueño J, and Crossa J. 2018. META-R (Multi Environment Trail Analysis with R for Windows) Version 6.03. CIMMYT Research Data \& Software Repository Network.

Alvarez MA, Tranquilli G, Lewis S, Kippes N, and Dubcovsky J. 2016. Genetic and physical mapping of the earliness per se locus Eps-A (m) 1 in Triticum monococcum identifies EARLY FLOWERING 3 (ELF3) as a candidate gene. Functional \& Integrative Genomics 16:365-382. 10.1007/s10142-016-0490-3

Assanga SO, Fuentealba M, Zhang GR, Tan C, Dhakal S, Rudd JC, Ibrahim AMH, Xue QW, Haley S, Chen JL, Chao SM, Baker J, Jessup K, and Liu SY. 2017. Mapping of quantitative trait loci for grain yield and its components in a US popular winter wheat TAM 111 using 90K SNPs. PLoS One 12. 10.1371/journal.pone.0189669

Borlaug NE. 1968. Wheat breeding and its impact on world food supply. Butterworths, Canberra, Australia.

Brinton J, Simmonds J, Minter F, Leverington-Waite M, Snape J, and Uauy C. 2017. Increased pericarp cell length underlies a major quantitative trait locus for grain weight in hexaploid wheat. New Phytologist 215:1026-1038. https://doi.org/10.1111/nph.14624

Cabral AL, Jordan MC, Larson G, Somers DJ, Humphreys DG, and McCartney CA. 2018. Relationship between QTL for grain shape, grain weight, test weight, milling yield, and plant height in the spring wheat cross RL4452/'AC Domain'. PLoS ONE 13:e0190681. 10.1371/journal.pone.0190681

Campbell KG, Bergman CJ, Gualberto DG, Anderson JA, Giroux MJ, Hareland G, Fulcher RG, Sorrells ME, and Finney PL. 1999. Quantitative Trait Loci Associated with Kernel Traits in a Soft $\times$ Hard Wheat Cross. Crop Science 39 . 10.2135/cropsci1999.0011183X003900040039x

Chen X, Min D, Yasir TA, and Hu Y-G. 2012. Evaluation of 14 morphological, yield-related and physiological traits as indicators of drought tolerance in Chinese winter bread wheat revealed by analysis of the membership function value of drought tolerance (MFVD). Field Crops Research 137:195-201. https://doi.org/10.1016/j.fcr.2012.09.008

Chu C, Wang S, Paetzold L, Wang Z, Hui K, Rudd JC, Xue Q, Ibrahim AMH, Metz R, Johnson CD, Rush CM, and Liu S. 2021. RNA-seq analysis reveals different drought tolerance

Peer] reviewing PDF | (2021:06:62177:1:2:NEW 13 Sep 2021) 
558

559

560

561

562

563

564

565

566

567

568

569

570

571

572

573

574

575

576

577

578

579

580

581

582

583

584

585

586

587

588

589

590

591

592

593

594

595

596

597

598

599

600

601

602 mechanisms in two broadly adapted wheat cultivars 'TAM 111' and 'TAM 112'. Scientific Reports 11:4301. 10.1038/s41598-021-83372-0

De Vita P, Nicosia OLD, Nigro F, Platani C, Riefolo C, Di Fonzo N, and Cattivelli L. 2007. Breeding progress in morpho-physiological, agronomical and qualitative traits of durum wheat cultivars released in Italy during the 20th century. European Journal of Agronomy 26:39-53. 10.1016/j.eja.2006.08.009

Dhakal S, Liu X, Girard A, Chu C, Yang Y, Wang S, Xue Q, Rudd JC, Ibrahim AMH, Awika JM, Jessup KE, Baker JA, Garza L, Devkota RN, Baker S, Johnson CD, Metz RP, and Liu S. 2021. Genetic dissection of end-use quality traits in two widely-adapted wheat cultivars 'TAM 111' and 'TAM 112'. Crop Science 61:1944-1959. https://doi.org/10.1002/csc2.20415

Dhakal S, Tan CT, Anderson V, Yu HJ, Fuentealba MP, Rudd JC, Haley SD, Xue QW, Ibrahim AMH, Garza L, Devkota RN, and Liu SY. 2018. Mapping and KASP marker development for wheat curl mite resistance in "TAM 112" wheat using linkage and association analysis. Molecular Breeding 38. 10.1007/s11032-018-0879-x

Dhungana P, Eskridge KM, Baenziger PS, Campbell BT, Gill KS, and Dweikat I. 2007. Analysis of genotype-by-environment interaction in wheat using a structural equation model and chromosome substitution lines. Crop Science 47:477-484. 10.2135/cropsci2006.06.0425

Doerge RW. 2002. Mapping and analysis of quantitative trait loci in experimental populations. Nature Reviews Genetics 3:43-52. 10.1038/nrg703

Gao F, Ma D, Yin G, Rasheed A, Dong Y, Xiao Y, Xia X, Wu X, and He Z. 2017. Genetic Progress in Grain Yield and Physiological Traits in Chinese Wheat Cultivars of Southern Yellow and Huai Valley since 1950. Crop Science 57:760-773. https://doi.org/10.2135/cropsci2016.05.0362

Grover G, Sharma A, Gill HS, Srivastava P, and Bains NS. 2018. Rht8 gene as an alternate dwarfing gene in elite Indian spring wheat cultivars. PLoS One 13:e0199330. 10.1371/journal.pone.0199330

Guo Y, Zhang G, Guo B, Qu C, Zhang M, Kong F, Zhao Y, and Li S. 2020. QTL mapping for quality traits using a high-density genetic map of wheat. PLOS ONE 15:e0230601. 10.1371/journal.pone.0230601

Hossain A, da Silva JAT, Lozovskaya MV, and Zvolinsky VP. 2012. High temperature combined with drought affect rainfed spring wheat and barley in South-Eastern Russia: I. Phenology and growth. Saudi Journal of Biological Sciences 19:473-487. 10.1016/j.sjbs.2012.07.005

International Wheat Genome Sequencing Consortium. 2014. A chromosome-based draft sequence of the hexaploid bread wheat (Triticum aestivum) genome. Science 345:1251788. 10.1126/science.1251788

Jin H, Wen W, Liu J, Zhai S, Zhang Y, Yan J, Liu Z, Xia X, and He Z. 2016. Genome-Wide QTL Mapping for Wheat Processing Quality Parameters in a Gaocheng 8901/Zhoumai 16 Recombinant Inbred Line Population. Frontiers in Plant Science 7. 10.3389/fpls.2016.01032

Juliana P, Poland J, Huerta-Espino J, Shrestha S, Crossa J, Crespo-Herrera L, Toledo FH, Govindan V, Mondal S, Kumar U, Bhavani S, Singh PK, Randhawa MS, He X, Guzman C, Dreisigacker S, Rouse MN, Jin Y, Pérez-Rodríguez P, Montesinos-López OA, Singh D, Mokhlesur Rahman M, Marza F, and Singh RP. 2019. Improving grain yield, stress

Peer) reviewing PDF | (2021:06:62177:1:2:NEW 13 Sep 2021) 
603

604

605

606

607

608

609

610

611

612

613

614

615

616

617

618

619

620

621

622

623

624

625

626

627

628

629

630

631

632

633

634

635

636

637

638

639

640

641

642

643

644

645

646

647

resilience and quality of bread wheat using large-scale genomics. Nature Genetics 51:1530-1539. 10.1038/s41588-019-0496-6

Kuchel H, Williams K, Langridge P, Eagles HA, and Jefferies SP. 2007. Genetic dissection of grain yield in bread wheat. II. QTL-by-environment interaction. Theoretical and Applied Genetics 115:1015-1027. 10.1007/s00122-007-0628-8

Lazar MD, Worrall WD, Peterson GL, Fritz AK, Marshall D, Nelson LR, and Rooney LW. 2004. Registration of 'TAM 111' wheat. Crop Science 44:355-356.

$10.2135 /$ cropsci2004.3550

Li SS, Jia JZ, Wei XY, Zhang XC, Li LZ, Chen HM, Fan YD, Sun HY, Zhao XH, Lei TD, Xu YF, Jiang FS, Wang HG, and Li LH. 2007. A intervarietal genetic map and QTL analysis for yield traits in wheat. Molecular Breeding 20:167-178. 10.1007/s11032-007-9080-3

Liu H, Searle IR, Mather DE, Able AJ, and Able JA. 2015. Morphological, physiological and yield responses of durum wheat to pre-anthesis water-deficit stress are genotypedependent. Crop and Pasture Science 66:1024-1038, 1015. 10.1071/CP15013

Liu S, Assanga SO, Dhakal S, Gu X, Tan C-T, Yang Y, Rudd J, Hays D, Ibrahim A, Xue Q, Chao S, Devkota R, Shachter C, Huggins T, Mohammed S, and Fuentealba MP. 2016. Validation of Chromosomal Locations of 90K Array Single Nucleotide Polymorphisms in US Wheat. Crop Science 56:10. 10.2135/cropsci2015.03.0194

Liu S, Rudd JC, Bai G, Haley SD, Ibrahim AMH, Xue Q, Hays DB, Graybosch RA, Devkota RN, and St. Amand P. 2014. Molecular Markers Linked to Important Genes in Hard Winter Wheat. Crop Sci 54:1304-1321. 10.2135/cropsci2013.08.0564

Lopes MS, Reynolds MP, Manes Y, Singh RP, Crossa J, and Braun HJ. 2012. Genetic Yield Gains and Changes in Associated Traits of CIMMYT Spring Bread Wheat in a "Historic" Set Representing 30 Years of Breeding. Crop Science 52:1123-1131. https://doi.org/10.2135/cropsci2011.09.0467

McIntosh R, Yamazaki Y, Devos KM, Dubcovsky J, Rogers WJ, and Appels R. 2003. Catalogue of gene symbols for wheat. : USDA-ARS, Genomics and Gene Discovery Unit, Albany, CA.

Meng L, Li H, Zhang L, and Wang J. 2015. QTL IciMapping: Integrated software for genetic linkage map construction and quantitative trait locus mapping in biparental populations. The Crop Journal 3:269-283. https://doi.org/10.1016/j.cj.2015.01.001

Mondal S, Singh RP, Mason ER, Huerta-Espino J, Autrique E, and Joshi AK. 2016. Grain yield, adaptation and progress in breeding for early-maturing and heat-tolerant wheat lines in South Asia. Field Crops Research 192:78-85. https://doi.org/10.1016/j.fcr.2016.04.017

Peterson BK, Weber JN, Kay EH, Fisher HS, and Hoekstra HE. 2012. Double Digest RADseq: An inexpensive method for de novo SNP discovery and genotyping in model and nonmodel species. PLoS One 7:e37135. 10.1371/journal.pone.0037135

Rasheed A, Wen W, Gao F, Zhai S, Jin H, Liu J, Guo Q, Zhang Y, Dreisigacker S, Xia X, and He Z. 2016. Development and validation of KASP assays for genes underpinning key economic traits in bread wheat. TAG Theoretical And Applied Genetics Theoretische Und Angewandte Genetik 129:18.

Rebetzke GJ, Ellis MH, Bonnett DG, Mickelson B, Condon AG, and Richards RA. 2012. Height reduction and agronomic performance for selected gibberellin-responsive dwarfing genes in bread wheat (Triticum aestivum L.). Field Crops Research 126:87-96.

https://doi.org/10.1016/j.fcr.2011.09.022

PeerJ reviewing PDF | (2021:06:62177:1:2:NEW 13 Sep 2021) 
648 Reddy SK, Liu S, Rudd JC, Xue Q, Payton P, Finlayson SA, Mahan J, Akhunova A, Holalu SV,

649

650

651

652

653

654

655

656

657

658

659

660

661

662

663

664

665

666

667

668

669

670

671

672

673

674

675

676

677

678

679

680

681

682

683

684

685

686

687

688

689

690

691

692

693 and Lu N. 2014. Physiology and transcriptomics of water-deficit stress responses in wheat cultivars TAM 111 and TAM 112. Journal of Plant Physiology 171:1289-1298. 10.1016/j.jplph.2014.05.005

Rudd JC, Devkota RN, Baker JA, Peterson GL, Lazar MD, Bean B, Worrall D, Baughman T, Marshall D, Sutton R, Rooney LW, Nelson LR, Fritz AK, Weng YQ, Morgan GD, and Seabourn BW. 2014. 'TAM 112' wheat, resistant to greenbug and wheat curl mite and adapted to the dryland production system in the Southern High Plains. Journal of Plant Registrations 8:291-297. 10.3198/jpr2014.03.0016crc

Saini HS, and Aspinall D. 1982. Abnormal Sporogenesis in Wheat (Triticum-Aestivum L) Induced by Short Periods of High-Temperature. Annals of Botany 49:835-846. 10.1093/oxfordjournals.aob.a086310

SAS Institue Inc. 2015. SAS/STAT 14.1 user's guide. Cary, NC.

Scarth R, and Law CN. 1984. The Control of the Day-Length Response in Wheat by the Group-2 Chromosomes. Zeitschrift Fur Pflanzenzuchtung-Journal of Plant Breeding 92:140-150.

Sourdille P, Snape JW, Cadalen T, Charmet G, Nakata N, Bernard S, and Bernard M. 2000. Detection of QTLs for heading time and photoperiod response in wheat using a doubledhaploid population. Genome 43:487-494. 10.1139/g00-013

Tan C-T, Yu H, Yang Y, Xu X, Chen M, Rudd JC, Xue Q, Ibrahim AMH, Garza L, Wang S, Sorrells ME, and Liu S. 2017. Development and validation of KASP markers for the greenbug resistance gene $\mathrm{Gb} 7$ and the Hessian fly resistance gene $\mathrm{H} 32$ in wheat. Theoretical and Applied Genetics 130:1867-1884. 10.1007/s00122-017-2930-4

Thapa S, Reddy SK, Fuentealba MP, Xue Q, Rudd JC, Jessup KE, Devkota RN, and Liu S. 2018. Physiological responses to water stress and yield of winter wheat cultivars differing in drought tolerance. Journal of Agronomy and Crop Science 204:347-358. doi:10.1111/jac.12263

Van Ooijen JW. 2006. JoinMap ${ }^{\circledR}$ 4.0: software for the calculation of genetic linkage maps in experimental population. In: Kyazma BV (ed) Wageningen, the Netherlands.

Worland AJ. 1996. The influence of flowering time genes on environmental adaptability in European wheats. Euphytica 89:49-57. 10.1007/Bf00015718

Worland AJ, Borner A, Korzun V, Li WM, Petrovic S, and Sayers EJ. 1998. The influence of photoperiod genes on the adaptability of European winter wheats (Reprinted from Wheat: Prospects for global improvement, 1998). Euphytica 100:385-394. 10.1023/A:1018327700985

Xing YZ, and Zhang QF. 2010. Genetic and Molecular Bases of Rice Yield. Annual Review of Plant Biology, Vol 61 61:421-442. 10.1146/annurev-arplant-042809-112209

Yang Y, Basnet BR, Ibrahim AMH, Rudd JC, Chen XM, Bowden RL, Xue QW, Wang SC, Johnson CD, Metz R, Mason RE, Hays DB, and Liu SY. 2019. Developing KASP markers on a major stripe rust resistance QTL in a popular wheat TAM 111 using 90K array and genotyping-by-sequencing SNPs. Crop Science 59:165-175.

10.2135/cropsci2018.05.0349

Yang Y, Chai Y, Zhang X, Lu S, Zhao Z, Wei D, Chen L, and Hu Y-G. 2020a. Multi-Locus GWAS of Quality Traits in Bread Wheat: Mining More Candidate Genes and Possible Regulatory Network. Frontiers in Plant Science 11. 10.3389/fpls.2020.01091

Yang Y, Dhakal S, Chu C, Wang S, Xue Q, Rudd JC, Ibrahim AMH, Jessup K, Baker J, Fuentealba MP, Devkota R, Baker S, Johnson CD, Metz R, and Liu S. 2020b. Genome 
694

695

696

697

698

699

700

701

702

703

704

705

706

707

708

709

710

711

712

713

714

715

716

717

718

719

720

721

722

723

wide identification of QTL associated with yield and yield components in two popular wheat cultivars TAM 111 and TAM 112. PLoS ONE 15. 10.1371/journal.pone.0237293

Zhang JL, Gizaw SA, Bossolini E, Hegarty J, Howell T, Carter AH, Akhunov E, and Dubcovsky J. 2018. Identification and validation of QTL for grain yield and plant water status under contrasting water treatments in fall-sown spring wheats. Theoretical and Applied Genetics 131:1741-1759. 10.1007/s00122-018-3111-9

\section{Figure tiles and legends}

Figure 1 GGE-Biplot analysis of yield and agronomic traits to classify mega-environments for each trait. Clusters of environments within a quadrant is in a mega-environment. ME1, ME2, ME3, ME4 are mega-environment 1, 2, 3, and 4 where lines performed very similarly. Individual Environments were Bushland, TX in 2011, 2012, 2017 as dryland (11BD, 12BD, 17BD), irrigated in 2017 (17BI), Chillicothe, TX in 2011, 2012 and 2014 as dryland (11CH, 12CH, $14 \mathrm{CH})$, Etter, TX with five irrigation levels $(40 \%, 50 \%, 65 \%, 75 \%$ and $100 \%)$ in 2011 (11EP1, 11EP2, 11EP3, 11EP4, 11EP5), three irrigation levels in 2012 (12EP1, 12EP2, 12EP3), four irrigation levels in 2013 (13EP2, 13EP3, 13EP4, 13EP5), two irrigation levels in 2014 (14EP4, 14EP5), and irrigated in 2017 (17EI), Uvalde, TX in 2012 as dryland (12UVLD = 12UVD), and with three irrigation levels in $2012(50 \%, 75 \%, 100 \%)$ (12UV5, 12UV7, 12UVL), irrigated in 2013 (13UVL), Clovis, NM irrigated in 2017 (17CVI). Me's for traits were a) heading days, b) plant height, c) test weight, ME1 included 12BD, 12EP2, 12UV7, 12UVL, 12UV5, 13EP3, and 14CH; ME2 included 11EP5, 12CH, 12EP1, 12EP3, 13EP2, 13EP4, 13EP5, 14EP4, 14EP5, 17BD, 17BI, and 17EI; d) grain yield, ME1 included 11CH, 14EP4, 14EP5, 17BI, and 17CVI; ME2 included 11BD, 11EP5, 12BD, 12EP1, 12EP2, 17EI; ME3 included 12CH, 12UVD, 13UVL, 17BD; ME4 included 12UV5, 12UV7, 12UVL, and 14CH.

Figure 2 Genetic maps showing the positions of QTL for grain yield and agronomic traits from QTL analysis in TAM $112 \times$ TAM 111 RIL population. Markers are represented by horizontal stripes inside a linkage group. Traits include grain yield (YLD), test weight (TW), plant height (HT), and heading date (HD). Identified QTL were designated in the format as

Qtrait.tamu.chrom.Mb. The bar length is the flanking marker intervals in cM. 


\section{Table $\mathbf{1}$ (on next page)}

Locations, cropping seasons, geographic coordinates, and climatic characterization of trials with growing seasons ending in year 2011, 2012, 2013, 2014 and 2017 at five different locations

a Irrigation levels: 10, no irrigation; 140, 40\% field capacity of irrigation; 150, 50\% field capacity of irrigation; $165,65 \%$ of field capacity irrigation, $175,75 \%$ of field capacity irrigation; 1100 , $100 \%$ of field capacity irrigation ${ }^{\mathrm{b}}$ Abbreviations: 11, Year 2011; 12, Year 2012; 13, Year 2013; 14, Year 2014; 17, Year 2017; BD, Bushland dry (I0), TX; BI, Bushland Irrigated (I100), TX; CH, Chillicothe (I0), TX; CVI, Clovis Irrigated (I100), NM; EP1, Etter (I0), TX; EP2, Etter (150), TX; EP3, Etter (165), TX; EP4, Etter (175), TX; EP5, Etter (100), TX; UVD, Uvalde dry (10), TX; UV5, Uvalde (I50), TX; UV7, Uvalde (I70), TX; UVL, Uvalde (I100), TX ' Seasonal Temperatures includes readings from plant in October of the previous years to harvesting in June of the current year: Maxav, average of the maximum temperatures during growing seasons; Av, average of the average temperature during growing seasons; Minav, average of the minimum temperature during growing seasons ${ }^{\mathrm{d}}$ Cumulative rainfall during the growing seasons. 
1 Table 1 Locations, cropping seasons, geographic coordinates, and climatic characterization of trials with growing seasons ending in year 2011, 2012, 2013, 2014 and 2017 at five different locations.

\begin{tabular}{|c|c|c|c|c|c|c|c|c|c|c|}
\hline \multirow[t]{2}{*}{ Location } & \multirow{2}{*}{$\begin{array}{l}\begin{array}{l}\text { Altitud } \\
\mathrm{e}\end{array} \\
\text { (masl) }\end{array}$} & \multirow[t]{2}{*}{ Latitude } & \multirow[t]{2}{*}{ Longitude } & \multirow[t]{2}{*}{ Season } & \multirow[t]{2}{*}{ Irrigation $^{\mathrm{a}}$} & \multirow[t]{2}{*}{ Environments ${ }^{\mathrm{b}}$} & \multicolumn{3}{|c|}{$\begin{array}{ll}\text { Seasonal } & \text { Temperature } \\
\left({ }^{\circ} \mathrm{C}\right)^{\mathrm{c}} & \end{array}$} & \multirow{2}{*}{$\begin{array}{l}\text { Rainfal } \\
\text { ld }^{\mathrm{d}} \\
(\mathrm{mm})\end{array}$} \\
\hline & & & & & & & $\operatorname{Max}_{\mathrm{av}}$ & Av. & $\operatorname{Min}_{\mathrm{av}}$ & \\
\hline \multirow[t]{3}{*}{ Bushland, TX } & 1098 & $35^{\circ} 16^{\prime} \mathrm{N}$ & $\begin{array}{l}102{ }^{\circ} 27^{\prime} \\
\mathrm{W}\end{array}$ & $\begin{array}{l}2010 / 201 \\
1\end{array}$ & $\mathrm{I}_{0}$ & $11 \mathrm{BD}$ & 16.83 & 11.78 & 3.11 & 128.27 \\
\hline & & & & $\begin{array}{l}2011 / 201 \\
2\end{array}$ & $\overline{I_{0}}$ & $12 \mathrm{BD}$ & 20.33 & 12.56 & 4.78 & 265.94 \\
\hline & & & & $\begin{array}{l}2016 / 201 \\
7\end{array}$ & $\mathrm{I}_{0}, \mathrm{I}_{100}$ & 17BD, 17BI & 21.17 & 12.83 & 4.56 & 275.59 \\
\hline \multirow[t]{3}{*}{$\begin{array}{l}\text { Chillicothe, } \\
\text { TX }\end{array}$} & 436 & $34^{\circ} 15^{\prime} \mathrm{N}$ & $99^{\circ} 30^{\prime} \mathrm{W}$ & $\begin{array}{l}2010 / 201 \\
1\end{array}$ & $\mathrm{I}_{0}$ & $11 \mathrm{CH}$ & 24.33 & 15.83 & 6.33 & 59.18 \\
\hline & & & & $\begin{array}{l}2011 / 201 \\
2\end{array}$ & $\overline{I_{0}}$ & $12 \mathrm{CH}$ & 24.44 & 16.11 & 9.33 & 230.12 \\
\hline & & & & $\begin{array}{l}2013 / 201 \\
4\end{array}$ & $\mathrm{I}_{0}$ & $14 \mathrm{CH}$ & 23.61 & 13.67 & 2.5 & 197.61 \\
\hline Clovis, NM & 1309 & $34^{\circ} 24^{\prime} \mathrm{N}$ & $\begin{array}{ll}103 & \circ 12^{\prime} \\
\mathrm{W} & \\
\end{array}$ & $\begin{array}{l}2016 / 201 \\
7\end{array}$ & $\mathrm{I}_{100}$ & $17 \mathrm{CVI}$ & 20.17 & 12.89 & 3.06 & 197.87 \\
\hline \multirow[t]{5}{*}{ Etter, TX } & 1117 & $\begin{array}{l}35 \text { o } 51 \\
\mathrm{~N}\end{array}$ & $\begin{array}{ll}101 & \text { o } 58^{\prime} \\
\mathrm{W} & \\
\end{array}$ & $\begin{array}{l}2010 / 201 \\
1\end{array}$ & $\begin{array}{l}\mathrm{I}_{40}, \mathrm{I}_{50}, \mathrm{I}_{65}, \mathrm{I}_{75}, \\
\mathrm{I}_{100},\end{array}$ & $\begin{array}{l}\text { 11EP1, 11EP2, 11EP3, 11EP4, } \\
\text { 11EP5 }\end{array}$ & 19.6 & 11.04 & 1.3 & 62 \\
\hline & & & & $\begin{array}{l}2011 / 201 \\
2\end{array}$ & $\mathrm{I}_{40}, \mathrm{I}_{50}, \mathrm{I}_{65}$ & 12EP1, 12EP2, 12EP3 & 19.4 & 11.48 & 2.9 & 243 \\
\hline & & & & $\begin{array}{l}2012 / 201 \\
3\end{array}$ & $\mathrm{I}_{50}, \mathrm{I}_{65}, \mathrm{I}_{75}, \mathrm{I}_{100}$ & 13ЕР2, 13ЕР3, 13ЕР4, 13ЕР5 & 18.8 & 10 & 1.4 & 81 \\
\hline & & & & $\begin{array}{l}2013 / 201 \\
4\end{array}$ & $\mathrm{I}_{75}, \mathrm{I}_{100}$ & 14EP4, 14EP5 & 17.8 & 9.19 & 0.6 & 138 \\
\hline & & & & $\begin{array}{l}2016 / 201 \\
7\end{array}$ & $\mathrm{I}_{100}$ & $17 \mathrm{EI}$ & 19.6 & 9.9 & -0.7 & 152.6 \\
\hline \multirow[t]{2}{*}{ Uvalde, TX } & 378 & $\begin{array}{l}29 \text { o } 21^{\prime} \\
\mathrm{N}\end{array}$ & 99 o $75^{\prime} \mathrm{W}$ & $\begin{array}{l}2011 / 201 \\
2\end{array}$ & $\mathrm{I}_{0}, \mathrm{I}_{50}, \mathrm{I}_{75}, \mathrm{I}_{100}$ & 12UVD, 12UV5, 12UV7, 12UVL & 25.83 & 19.17 & 11.39 & 253.75 \\
\hline & & & & $\begin{array}{l}2012 / 201 \\
3\end{array}$ & $\mathrm{I}_{0}, \mathrm{I}_{100}$ & 13UVD, 13UVL & 25.78 & 19.11 & 11 & 262.13 \\
\hline
\end{tabular}

5 a Irrigation levels: I0, no irrigation; I40, 40\% field capacity of irrigation; I50, 50\% field capacity of irrigation; I65, 65\% of field capacity irrigation, I75, 75\% of field capacity irrigation; I100, 100\% of field capacity irrigation 
7 b Abbreviations: 11, Year 2011; 12, Year 2012; 13, Year 2013; 14, Year 2014; 17, Year 2017; BD, Bushland dry (I0), TX; BI, Bushland Irrigated (I100), TX; CH, 8 Chillicothe (I0), TX; CVI, Clovis Irrigated (I100), NM; EP1, Etter (I0), TX; EP2, Etter (I50), TX; EP3, Etter (I65), TX; EP4, Etter (I75), TX; EP5, Etter (100), 9 TX; UVD, Uvalde dry (I0), TX; UV5, Uvalde (I50), TX; UV7, Uvalde (I70), TX; UVL, Uvalde (I100), TX

$10{ }^{\mathrm{c}}$ Seasonal Temperatures includes readings from plant in October of the previous years to harvesting in June of the current year: Maxav, average of the maximum 11 temperatures during growing seasons; Av, average of the average temperature during growing seasons; Minav, average of the minimum temperature during growing 12 seasons

$13{ }^{\mathrm{d}}$ Cumulative rainfall during the growing seasons. 


\section{Table 2 (on next page)}

Analysis of variance, heritability and mean performance of grain yield and agronomic traits

${ }^{a} \sigma 2 G e n o$, genotypic variance ${ }^{b} \sigma 2 E n v$, variance due to environment ${ }^{c} \sigma 2 R e p(E n v)$, variance due to replication nested within environments ${ }^{d} \sigma 2$ lblk (Rep*Env), variance due to incomplete block nested within replication (environment) ${ }^{\mathrm{e}} \mathrm{\sigma} 2 \mathrm{GE}$, variance due to genotype-byenvironment interaction ${ }^{f} \sigma 2$ Res, residual variance ${ }^{9} \mathrm{~h} 2$, entry-mean heritability *, **, significant at 0.05 , and 0.01 probability levels, respectively 
1 Table 2 Analysis of variance, heritability and mean performance of grain yield and agronomic traits.

\begin{tabular}{|c|c|c|c|c|c|c|c|c|c|c|c|c|}
\hline Traits & Units & $\sigma_{\text {Geno }}^{2}{ }^{a}$ & $\sigma_{\text {Env }}^{2}$ & $\begin{array}{l}\sigma_{\text {Rep }}^{2}{ }^{c} \\
\text { (Env) }\end{array}$ & $\begin{array}{l}\sigma_{\text {IIblk (Rep*Env) }}^{2} \\
\text { d }\end{array}$ & $\sigma_{\mathrm{GE}}^{2} \mathrm{e}^{\mathrm{e}}$ & $\sigma^{2}{ }^{\mathrm{fes}}{ }^{\mathrm{f}}$ & $\begin{array}{l}\text { RIL } \\
\mathrm{s}\end{array}$ & & & Parents & \\
\hline Traits & & & & & & & & $h^{2 g}$ & $\begin{array}{l}\text { LS } \\
\text { D }\end{array}$ & $\overline{\mathrm{X}} \pm \mathrm{SD}$ & $\begin{array}{l}\text { TAM } \\
112\end{array}$ & $\begin{array}{l}\text { TAM } \\
111\end{array}$ \\
\hline $\begin{array}{ll}\text { Grain } & \text { yield } \\
\text { (YLD) } & \end{array}$ & $\mathrm{g} \mathrm{m}^{-2}$ & $\begin{array}{l}265.6^{*} \\
*\end{array}$ & $\begin{array}{l}17972.0 * \\
*\end{array}$ & $281.5 * *$ & $575.6 * *$ & $\begin{array}{l}853.3 * \\
*\end{array}$ & $\begin{array}{l}795.7 * \\
*\end{array}$ & 0.77 & $\begin{array}{l}55 . \\
3\end{array}$ & $\begin{array}{ll}287.7 & \pm \\
139.4 & \end{array}$ & 304.4 & 298.6 \\
\hline Test weight (TW) & $\mathrm{kg} \mathrm{m}^{-3}$ & $\begin{array}{l}144.1 * \\
*\end{array}$ & $538.3 * *$ & 13.2 & 21.5 & $\begin{array}{l}135.8^{*} \\
*\end{array}$ & $26.5 * *$ & 0.94 & 10 & $760.6 \pm 27.0$ & 767 & 770.1 \\
\hline $\begin{array}{ll}\text { Heading } & \text { Date } \\
(\mathrm{HD}) & \\
\end{array}$ & $\begin{array}{l}\text { Days from Jan } \\
1\end{array}$ & $3.05 * *$ & $15.46^{* *}$ & 0.01 & $0.21 * *$ & $1.30 * *$ & $1.28 * *$ & 0.96 & $\begin{array}{l}2.2 \\
2 \\
\end{array}$ & $115.5 \pm 4.01$ & 113.68 & 117.36 \\
\hline Plant Height (HT) & $\mathrm{cm}$ & $4.31 * *$ & $404.71 * *$ & 0.83 & $2.41 * *$ & $3.48 * *$ & $\begin{array}{l}13.16^{*} \\
*\end{array}$ & 0.87 & $\begin{array}{l}7.1 \\
1\end{array}$ & $73.8 \pm 19.01$ & 72.74 & 73.95 \\
\hline
\end{tabular}

$4{ }^{\mathrm{a}}$ o2Geno, genotypic variance

$5{ }^{\mathrm{b}} \sigma 2$ Env, variance due to environment

$6{ }^{c} \sigma 2 \operatorname{Rep}($ Env), variance due to replication nested within environments

7 d $\sigma 2 \operatorname{Iblk}($ Rep*Env), variance due to incomplete block nested within replication (environment)

8 e $\sigma 2 \mathrm{GE}$, variance due to genotype-by-environment interaction

$9 \mathrm{f} \sigma 2 \mathrm{Res}$, residual variance

$10 \mathrm{~g}$ h2, entry-mean heritability

$11 *$, **, significant at 0.05 , and 0.01 probability levels, respectively 


\section{Table 3(on next page)}

Consistent and pleiotropic QTL for grain yield and agronomic traits detected from individual and multiple environment QTL analysis

${ }^{\text {a }}$ Physical position based on IWGSC RefSeq v 1.0 Mega base pair position. ${ }^{\mathrm{b}}$ Trait abbreviations: grain yield (YLD), test weight (TW), days to heading (HD), and plant height (HT). ' Abbreviations: 11, Year 2011; 12, Year 2012; 13, Year 2013; 14, Year 2014; 17, Year 2017; BD, Bushland dry (10), TX; BI, Bushland Irrigated (I100), TX; CH, Chillicothe (I0), TX; CVI, Clovis Irrigated (I100), NM; EP1, Etter (10), TX; EP2, Etter (150), TX; EP3, Etter (165), TX; EP4, Etter (175), TX; EP5, Etter (100), TX; UVD, Uvalde dry (I0), TX; UV5, Uvalde (150), TX; UV7, Uvalde (170), TX; UVL, Uvalde (I100), TX. Ind Env-ADD, single environment QTL analysis; Multi Env-ADD, single trait multiple environment QTL analysis; Ind ME-ADD, Individual mega environment QTL analysis; Across ME-ADD, single trait multiple mega environment QTL analysis. Environment 1 to 28 for yield are: 11BD, 11CH, 11EP1, 11EP2, 11EP3, 11EP4, 11EP5, 12BD, 12CH, 12EP1, 12EP2, 12EP3, 12UV5, 12UV7, 12UVL, 12UVD, 13EP2, 13EP3, 13EP4, 13EP5, 13UVL, 14CH, 14EP4, 14EP5, 17BD, 17BI, 17CVI, and 17El. Environment 1 to 19 for test weight are: 11EP5, 12BD, 12CH, 12EP1, 12EP2, 12EP3, 12UV7, 12UVL, 12UV5, 13EP2, 13EP3, 13EP4, 13EP5, 14CH, 14EP4, 14EP5, 17BD, 17BI, and 17El. Environment 1 to 11 for height are: 11BD, 11EP1, 11EP2, 11EP3, 11EP4, 11EP5, 12BD, 12CH,1 7BD, 17CVI, and 17El. Environment 1 to 11 heading date are: 11BD, 11EP1, 11EP2, 11EP3, 11EP4, 11EP5, 12BD, 12CH, 17BD, 17CVI, and 17El. Mega-environments for traits: YLD had ME1 (11CH, 14EP4, 14EP5, 17BI, and 17CVI), ME2 (11BD, 11EP5, 12BD,12EP1, 12EP2, and 17EI), ME3 (12CH, 12UVD, 13UVL, and 17BD), and ME4 (12UV5, 12UV7, 12UVL, and 14CH); TW had ME1 (12BD, 12EP2, 12UV7, 12UVL, 12UV5, 13EP3, and 14CH) and ME2 (11EP5, 12CH, 12EP1, 12EP3, 13EP2, 13EP4, 13EP5, 14EP4, 14EP5, 17BD, 17BI, and 17EI). HT had ME1 (11EP3, 11BD, 12BD, 17CVI, 12CH), ME2 (11EP1, 11EP2, 11EP4, 11EP5, 17BD, 17EI). HD had ME1 
(12EP2, 11EP4, 11BD, 12EP1, 17BD) and ME2 (12EP3, 12BD, 11EP5, 11EP1, 11EP3). ' Linkage group. ${ }^{e}$ Centi Morgan distance. ${ }^{f}$ QTL $95 \%$ confidence interval ${ }^{9}$ Logarithm of odds, A, LOD due to $A ; A * E, L O D$ due to $A * E$ interaction. ${ }^{\text {h }}$ Phenotypic variance explained, $A$, PVE explained by Additive effect, $A * E, P V E$ by additive-by-environment interaction effect. ${ }^{~}$ Additive effects of the QTL. Positive value indicates the favorable allele came from female parent TAM 112 and negative value indicates the favorable allele came from male parent TAM 111. 
2 Table 3: Consistent and pleiotropic QTL for grain yield and agronomic traits detected from individual and multiple environment QTL analysis.

\begin{tabular}{|c|c|c|c|c|c|c|c|c|c|c|c|c|c|c|c|c|c|c|c|}
\hline $\begin{array}{l}\text { QTL } \\
\text { (underlined } \\
\text { nvolved } \\
\text { nteractions) } \\
\end{array}$ & Chr & $\begin{array}{l}\text { Positi } \\
\text { on }^{\mathrm{a}} \\
(\mathrm{Mb})\end{array}$ & \begin{tabular}{|l}
$\operatorname{Tr}$ \\
ait \\
b
\end{tabular} & Environment ${ }^{\mathfrak{c}}$ & $\begin{array}{l}\text { Lin } \\
\text { kag } \\
\mathrm{e}^{\mathrm{d}}\end{array}$ & $\begin{array}{l}\text { Peak } \\
\text { e } \\
(\mathrm{cM} \\
)\end{array}$ & $\begin{array}{l}\text { QTL } \\
\mathrm{CI}^{\mathrm{f}} \\
(\mathrm{cM}) \\
\end{array}$ & $\begin{array}{l}\text { LOD } \\
\mathrm{g}\end{array}$ & $\begin{array}{l}\text { LOD } \\
(A)\end{array}$ & $\begin{array}{l}\text { LOD } \\
\left(A^{*}\right. \\
\text { E) }\end{array}$ & $\begin{array}{l}\text { PVE } \\
\text { h } \\
(\%)\end{array}$ & $\begin{array}{l}\mathrm{PVE} \\
(\mathrm{A}) \\
(\%) \\
\end{array}$ & $\begin{array}{l}\text { PVE } \\
\left(A^{*}\right. \\
\text { E) } \\
(\%) \\
\end{array}$ & $\mathrm{ADD}^{\mathrm{i}}$ & $\begin{array}{l}\text { SNP alleles } \\
\text { increase traits }\end{array}$ & $\begin{array}{l}\text { Left } \\
\text { SNP } \\
\text { s } \\
\text { allel } \\
\text { es }\end{array}$ & \begin{tabular}{|l|} 
Right \\
SNPs \\
alleles \\
k
\end{tabular} & $\begin{array}{l}\text { Pleio } \\
\text { tropi } \\
\mathrm{c} \\
\text { QTL } \\
\end{array}$ & $\begin{array}{l}\text { Cit } \\
\text { QT }\end{array}$ \\
\hline $\begin{array}{l}\text { Qyld.tamu.1 } \\
\text { A.412 }\end{array}$ & $1 \mathrm{~A}$ & 411.7 & $\begin{array}{l}\mathrm{Y} \\
\mathrm{L} \\
\mathrm{D} \\
\end{array}$ & 17EI, AcrossME2 & $1 \mathrm{~A}$ & 58 & $\begin{array}{l}57.5- \\
58.5\end{array}$ & $\begin{array}{l}5.2- \\
6.8 \\
\end{array}$ & 0.4 & 6.4 & $\begin{array}{l}8.3- \\
12.9 \\
\end{array}$ & 0.8 & 7.5 & \begin{tabular}{|l}
$-1.42-(-$ \\
$10.22)$ \\
\end{tabular} & TAM 111 & $\mathrm{C} / \underline{\mathrm{T}}$ & $\mathrm{G} / \mathrm{A}$ & & $\mathrm{Ya}$ \\
\hline $\begin{array}{l}\text { Qyld.tamu.1 } \\
\text { A.586 }\end{array}$ & $1 \mathrm{~A}$ & 585.6 & \begin{tabular}{l|}
$\mathrm{Y}$ \\
$\mathrm{L}$ \\
$\mathrm{D}$
\end{tabular} & ME3, Across ME1234 & $1 \mathrm{~A}$ & 172 & $\begin{array}{l}171.5 \\
172.5\end{array}$ & $\begin{array}{l}24.9- \\
25.2\end{array}$ & 2.8 & 22.4 & $\begin{array}{l}16.8- \\
21.2\end{array}$ & -2.8 & 18.4 & $\begin{array}{l}-1.94-(- \\
11.1)\end{array}$ & TAM 111 & $\mathrm{C} / \underline{\mathrm{T}}$ & $\underline{\mathrm{A}} / \mathrm{G}$ & & $\begin{array}{l}\text { Ya } \\
\text { Jul }\end{array}$ \\
\hline $\begin{array}{l}\text { Qyld.tamu.1 } \\
\text { A.587 }\end{array}$ & $1 \mathrm{~A}$ & 587.0 & \begin{tabular}{l|}
$\mathrm{Y}$ \\
$\mathrm{L}$ \\
$\mathrm{D}$
\end{tabular} & ME3, Across ME1234 & $1 \mathrm{~A}$ & 174 & $\begin{array}{l}173.5- \\
175\end{array}$ & $\begin{array}{l}34.9- \\
36.3 \\
\end{array}$ & 12.0 & 24.3 & $\begin{array}{l}12.0- \\
25.0\end{array}$ & 14.6 & 20.6 & $\begin{array}{l}4.43- \\
13.54 \\
\end{array}$ & TAM 112 & $\mathrm{~A} / \underline{\mathrm{T}}$ & $\mathrm{T} / \underline{\mathrm{G}}$ & & $\begin{array}{l}\mathrm{Al} \\
\mathrm{Zh}\end{array}$ \\
\hline $\begin{array}{l}\text { Qyld.tamu.1 } \\
\text { D.422 }\end{array}$ & $\mathrm{p} 3 \mathrm{~B}$ & 421.8 & \begin{tabular}{l|}
$\mathrm{Y}$ \\
$\mathrm{L}$ \\
$\mathrm{D}$
\end{tabular} & $12 \mathrm{CH}$, across all env, AcrossME 3 & $1 \mathrm{D}$ & 69 & $\begin{array}{l}68.5- \\
69.5\end{array}$ & $\begin{array}{l}5.6- \\
17.0\end{array}$ & $\begin{array}{l}3.1- \\
3.7\end{array}$ & $\begin{array}{l}3.2- \\
13.9\end{array}$ & $\begin{array}{l}5.6- \\
12.7\end{array}$ & $\begin{array}{l}3.6- \\
4.2\end{array}$ & $\begin{array}{l}1.4- \\
9.1\end{array}$ & $\begin{array}{l}1.86- \\
6.87\end{array}$ & TAM 112 & $\mathrm{~T} / \underline{\mathrm{C}}$ & $\underline{\mathrm{C}} / \mathrm{A}$ & TW & Ya \\
\hline $\begin{array}{l}\text { Qyld.tamu.3 } \\
\text { B.49 }\end{array}$ & 3B & 48.6 & $\begin{array}{l}\mathrm{Y} \\
\mathrm{L} \\
\mathrm{D}\end{array}$ & 12UVL, AcrossME4 & 3B & 5 & $\begin{array}{l}4.5- \\
5.5\end{array}$ & $\begin{array}{l}5.0- \\
7.5 \\
\end{array}$ & 3.2 & 4.4 & $\begin{array}{l}9.5- \\
9.8 \\
\end{array}$ & 4.4 & 5.0 & \begin{tabular}{|l}
$-6.75-(-$ \\
$17.58)$ \\
\end{tabular} & TAM 111 & $\mathrm{G} / \underline{\mathrm{A}}$ & $\mathrm{G} / \underline{\mathrm{C}}$ & & \\
\hline $\begin{array}{l}\text { Qyld.tamu.4 } \\
\text { B.267 }\end{array}$ & $4 \mathrm{~B}$ & 266.8 & $\begin{array}{l}\mathrm{Y} \\
\mathrm{L} \\
\mathrm{D}\end{array}$ & 17CVI, across all env, AcrossME1 & $4 \mathrm{~B}$ & 39 & $\begin{array}{l}38.5- \\
39.5\end{array}$ & $\begin{array}{l}20.4- \\
28.1\end{array}$ & $\begin{array}{l}0.2- \\
1.5\end{array}$ & $\begin{array}{l}22.2- \\
27.9\end{array}$ & $-\begin{array}{l}22.3- \\
63.5 \\
\end{array}$ & $\begin{array}{l}-0.2- \\
1.3 \\
\end{array}$ & $\begin{array}{l}35.0- \\
63.3\end{array}$ & $\begin{array}{l}0.42-(- \\
37.41)\end{array}$ & $\begin{array}{l}\text { TAM 112, } \\
\text { TAM } 111\end{array}$ & $\mathrm{G} / \underline{\mathrm{A}}$ & $\underline{\mathrm{C}} / \mathrm{T}$ & & \\
\hline $\begin{array}{l}\text { Qyld.tamu.4 } \\
\text { B.659 }\end{array}$ & $4 \mathrm{~B}$ & 659.2 & $\begin{array}{l}\mathrm{Y} \\
\mathrm{L} \\
\mathrm{D}\end{array}$ & 14EP4, AcrossME1 & $4 \mathrm{~B}$ & 94 & $\begin{array}{l}93.5- \\
94.5\end{array}$ & $\begin{array}{l}3.6- \\
6.8\end{array}$ & 5.6 & 1.2 & $\begin{array}{l}6.5- \\
9.8 \\
\end{array}$ & 4.9 & 1.6 & $\begin{array}{l}6.43- \\
9.88 \\
\end{array}$ & TAM 112 & $\underline{\mathrm{A}} / \mathrm{G}$ & $\underline{\mathrm{A}} / \mathrm{G}$ & HD & Ya \\
\hline $\begin{array}{l}\text { Qyld.tamu.4 } \\
\text { B.661 }\end{array}$ & $4 \mathrm{~B}$ & 660.9 & $\begin{array}{l}\mathrm{Y} \\
\mathrm{L} \\
\mathrm{D}\end{array}$ & 12UVLD, AcrossME3 & 4B & 99 & $\begin{array}{l}97.5- \\
100.5\end{array}$ & $\begin{array}{l}4.3- \\
5.3\end{array}$ & 3.0 & 2.3 & $\begin{array}{l}8.4- \\
11.9 \\
\end{array}$ & 3.3 & 5.0 & $\begin{array}{l}3.28- \\
9.65\end{array}$ & TAM 112 & $\mathrm{~T} / \underline{\mathrm{C}}$ & $\mathrm{G} / \underline{\mathrm{A}}$ & & $\mathrm{Ya}$ \\
\hline $\begin{array}{l}\text { Qyld.tamu.4 } \\
\text { D.21 } \\
\end{array}$ & $4 \mathrm{D}$ & 20.6 & $\begin{array}{l}\mathrm{Y} \\
\mathrm{L} \\
\mathrm{D} \\
\end{array}$ & 17CVI, AcrossME1, ME1, Across ME1234 & $4 \mathrm{D}$ & 1 & $0-4.5$ & $\begin{array}{l}5.4- \\
8.4 \\
\end{array}$ & $\begin{array}{l}4.1- \\
6.4 \\
\end{array}$ & $\begin{array}{l}2.1- \\
2.2 \\
\end{array}$ & $\begin{array}{l}4.9- \\
19.4 \\
\end{array}$ & $\begin{array}{l}4.8- \\
5.5 \\
\end{array}$ & $\begin{array}{l}3.1- \\
8.5 \\
\end{array}$ & \begin{tabular}{|l}
$-2.55-(-$ \\
$17.32)$
\end{tabular} & TAM 111 & $\underline{\mathrm{A}} / \mathrm{G}$ & $\underline{T} / \mathrm{C}$ & HT & $\mathrm{Ya}$ \\
\hline $\begin{array}{l}\text { Qyld.tamu.4 } \\
\text { D.110 }\end{array}$ & $4 \mathrm{D}$ & 109.8 & $\begin{array}{l}\mathrm{Y} \\
\mathrm{L} \\
\mathrm{D}\end{array}$ & 17BI, across all env, AcrossME1 & 4D & 13 & $\begin{array}{l}12.5- \\
13.5\end{array}$ & $\begin{array}{l}8.3- \\
18.0\end{array}$ & $\begin{array}{l}2.4- \\
8.6\end{array}$ & \begin{tabular}{|l|}
$3.1-$ \\
15.6
\end{tabular} & $\begin{array}{l}18.4- \\
41.3 \\
\end{array}$ & $\begin{array}{l}2.8- \\
7.9\end{array}$ & $\begin{array}{l}12.4- \\
38.5\end{array}$ & $\begin{array}{l}-1.64-(- \\
28.06)\end{array}$ & TAM 111 & $\mathrm{C} / \underline{\mathrm{T}}$ & $\underline{\mathrm{T}} / \mathrm{C}$ & TW & $\begin{array}{l}\mathrm{Dh} \\
\mathrm{Ya}\end{array}$ \\
\hline Qyld.tamu.4 & $4 \mathrm{D}$ & 445.5 & $\mathrm{Y}$ & 14CH, across all env, AcrossME4 & $4 \mathrm{D}$ & 28 & $27.5-$ & $13.4-$ & $-0.2-$ & $12.7-$ & $-2.3-$ & $0.2-$ & $0.8-$ & $-0.47-$ & TAM 111 & $\underline{\mathrm{T}} / \mathrm{C}$ & $\mathrm{A} / \underline{\mathrm{G}}$ & & \\
\hline
\end{tabular}




\begin{tabular}{|c|c|c|c|c|c|c|c|c|c|c|c|c|c|c|c|c|c|c|c|}
\hline$D .446$ & & & $\begin{array}{l}\mathrm{L} \\
\mathrm{D}\end{array}$ & & & & 28.5 & 21.2 & 1.1 & 21.0 & 28.2 & 1.6 & 12.7 & 8.59 & & & & & \\
\hline $\begin{array}{l}\text { Qyld.tamu.6 } \\
\text { A.12 } \\
\end{array}$ & $6 \mathrm{~A}$ & 12.4 & $\begin{array}{l}\mathrm{Y} \\
\mathrm{L} \\
\mathrm{D}\end{array}$ & 17BI & $6 \mathrm{~A}$ & 20 & $\begin{array}{l}19.5- \\
20.5\end{array}$ & 4.4 & & & 8.9 & & & -19.58 & TAM 111 & $\mathrm{G} / \underline{\mathrm{C}}$ & $\mathrm{T} / \underline{\mathrm{G}}$ & TW & $\mathrm{Ya}$ \\
\hline $\begin{array}{l}\text { Qyld.tamu.6 } \\
\text { A.609 }\end{array}$ & $6 \mathrm{~A}$ & 608.5 & $\begin{array}{l}\mathrm{Y} \\
\mathrm{L} \\
\mathrm{D}\end{array}$ & ME3, Across ME1234 & $6 \mathrm{~A}$ & 139 & $\begin{array}{l}138.5- \\
139.5\end{array}$ & $\begin{array}{l}3.7- \\
5.4\end{array}$ & 0.1 & 5.3 & $\begin{array}{l}1.4- \\
5.2\end{array}$ & 0.1 & 5.0 & $\begin{array}{l}-0.42-(- \\
3.18)\end{array}$ & TAM 111 & $\underline{T} / \mathrm{C}$ & $\underline{\mathrm{T}} / \mathrm{C}$ & TW & \\
\hline $\begin{array}{l}\text { Qyld.tamu.7 } \\
\text { B.16 }\end{array}$ & 7B & 15.6 & \begin{tabular}{|l}
$\mathrm{Y}$ \\
$\mathrm{L}$ \\
$\mathrm{D}$ \\
\end{tabular} & 12CH, AcrossME3, ME3, Across ME1234 & $\begin{array}{l}7 \mathrm{~B} \\
1 \\
\end{array}$ & 24 & $\begin{array}{l}21.5- \\
24.5\end{array}$ & $\begin{array}{l}6.0- \\
8.4 \\
\end{array}$ & $\begin{array}{l}2.4- \\
4.3 \\
\end{array}$ & $\begin{array}{l}4.2- \\
6.0 \\
\end{array}$ & $\begin{array}{l}3.3- \\
10.9 \\
\end{array}$ & $\begin{array}{l}2.5- \\
4.9 \\
\end{array}$ & $\begin{array}{l}1.8- \\
2.0\end{array}$ & $\begin{array}{l}-1.87-(- \\
7.23)\end{array}$ & TAM 111 & $\underline{\mathrm{A}} / \mathrm{C}$ & $\mathrm{T} / \mathrm{C}$ & HD & Ya \\
\hline $\begin{array}{l}\text { Qyld.tamu.7 } \\
\text { D.61 }\end{array}$ & $7 \mathrm{D}$ & 60.6 & \begin{tabular}{|l|}
$\mathrm{Y}$ \\
$\mathrm{L}$ \\
$\mathrm{D}$
\end{tabular} & 12UVD, across all env, AcrossME3 & $7 \mathrm{D}$ & 79 & $\begin{array}{l}78.5- \\
80.5 \\
\end{array}$ & $\begin{array}{l}3.5- \\
22.1\end{array}$ & $\begin{array}{l}1.4- \\
11.2 \\
\end{array}$ & $\begin{array}{l}1.6- \\
20.7\end{array}$ & $\begin{array}{l}9.7- \\
20.1\end{array}$ & $\begin{array}{l}1.6- \\
13.3 \\
\end{array}$ & $\begin{array}{l}0.5- \\
18.5 \\
\end{array}$ & $\begin{array}{l}1.24- \\
8.73 \\
\end{array}$ & TAM 112 & $\underline{\mathrm{T}} / \mathrm{C}$ & $\mathrm{C} / \underline{\mathrm{T}}$ & $\begin{array}{l}\text { TW, } \\
\text { HT }\end{array}$ & $\mathrm{Jul}$ \\
\hline \begin{tabular}{|l} 
Qyld.tamu.7 \\
D.64
\end{tabular} & $7 \mathrm{D}$ & 64.3 & \begin{tabular}{|l|}
$\mathrm{Y}$ \\
$\mathrm{L}$ \\
$\mathrm{D}$ \\
\end{tabular} & $12 \mathrm{CH}, 17 \mathrm{BD}, \mathrm{ME} 3$ & $7 \mathrm{D}$ & 80 & \begin{tabular}{|l|}
$77.5-$ \\
80.5 \\
\end{tabular} & $\begin{array}{l}3.9- \\
6.4 \\
\end{array}$ & & & $\begin{array}{l}2.5- \\
12.5 \\
\end{array}$ & & & $\begin{array}{l}4.28- \\
6.45 \\
\end{array}$ & TAM 112 & $\mathrm{C} / \underline{\mathrm{T}}$ & $\underline{\mathrm{T}} / \mathrm{C}$ & HT & $\mathrm{Ca}$ \\
\hline $\begin{array}{l}\text { Qyld.tamu.7 } \\
\text { D.84 }\end{array}$ & 7D & 84.3 & $\begin{array}{l}\mathrm{Y} \\
\mathrm{L} \\
\mathrm{D}\end{array}$ & 17BI, across all env, AcrossME1 & 7D & 97 & $\begin{array}{l}95.5- \\
98.5\end{array}$ & $\begin{array}{l}5.0- \\
17.0\end{array}$ & $\begin{array}{l}0.0- \\
6.6\end{array}$ & $\begin{array}{l}1.0- \\
17.0\end{array}$ & $\begin{array}{l}11.1- \\
28.9\end{array}$ & $\begin{array}{l}0.0- \\
5.8\end{array}$ & $\begin{array}{l}5.5- \\
28.9\end{array}$ & $\begin{array}{l}-0.004- \\
(-21.80)\end{array}$ & TAM 111 & G/A & $\mathrm{A} / \underline{\mathrm{G}}$ & & \\
\hline $\begin{array}{l}\text { Qyld.tamu.7 } \\
\text { D.591 }\end{array}$ & $7 \mathrm{D}$ & 591.2 & \begin{tabular}{|l|}
$\mathrm{Y}$ \\
$\mathrm{L}$ \\
$\mathrm{D}$
\end{tabular} & 12BD, AcrossME2 & $7 \mathrm{D}$ & 181 & $\begin{array}{l}180.5- \\
181.5\end{array}$ & $\begin{array}{l}4.7- \\
7.0\end{array}$ & 2.0 & 5.0 & $\begin{array}{l}7.8- \\
13.5\end{array}$ & 3.5 & 4.4 & $\begin{array}{l}2.47- \\
3.00\end{array}$ & TAM 112 & $\mathrm{~A} / \underline{\mathrm{G}}$ & $\mathrm{C} / \underline{\mathrm{T}}$ & & $\begin{array}{l}\text { Ya } \\
\text { Ta }\end{array}$ \\
\hline $\begin{array}{l}\text { Qtw.tamu.1 } \\
\text { A.12 }\end{array}$ & $1 \mathrm{~A}$ & 11.8 & \begin{tabular}{|l|}
$\mathrm{T}$ \\
$\mathrm{W}$ \\
\end{tabular} & across all env & $1 \mathrm{~A}$ & 9 & \begin{tabular}{|l|}
$8.5-$ \\
9.5 \\
\end{tabular} & 12.6 & 7.8 & 4.8 & 1.6 & 1.0 & 0.6 & -1.87 & TAM 111 & $\underline{\mathrm{A}} / \mathrm{G}$ & $\mathrm{A} / \underline{\mathrm{G}}$ & $\mathrm{y}$ & $\mathrm{Gu}$ \\
\hline $\begin{array}{l}\text { Qtw.tamu.1 } \\
\text { A.381 }\end{array}$ & $1 \mathrm{~A}$ & 380.7 & \begin{tabular}{|l|}
$\mathrm{T}$ \\
$\mathrm{W}$ \\
\end{tabular} & across all env, AcrossME2 & $1 \mathrm{~A}$ & 51 & $\begin{array}{l}50.5- \\
51.5\end{array}$ & $\begin{array}{l}9.0- \\
14.7\end{array}$ & \begin{tabular}{|l|}
$6.1-$ \\
10.6 \\
\end{tabular} & $\begin{array}{l}2.9- \\
4.1\end{array}$ & $\begin{array}{l}1.9- \\
2.3\end{array}$ & $\begin{array}{l}1.4- \\
1.5 \\
\end{array}$ & $\begin{array}{l}0.5- \\
0.8\end{array}$ & $\begin{array}{l}-2.06-(- \\
2.18)\end{array}$ & TAM 111 & $\mathrm{C} / \underline{\mathrm{G}}$ & $\mathrm{G} / \underline{\mathrm{A}}$ & & \\
\hline $\begin{array}{l}\text { Qtw.tamu.1 } \\
\text { A.485 }\end{array}$ & $1 \mathrm{~A}$ & 485.2 & \begin{tabular}{|l|}
$\mathrm{T}$ \\
$\mathrm{W}$ \\
\end{tabular} & 13EP5, across all env, AcrossME2 & $1 \mathrm{~A}$ & 64 & $\begin{array}{l}63.5- \\
64.5\end{array}$ & \begin{tabular}{|l|}
$4.1-$ \\
17.4 \\
\end{tabular} & $\begin{array}{l}7.4- \\
11.5 \\
\end{array}$ & $\begin{array}{l}4.3- \\
5.8\end{array}$ & \begin{tabular}{|l}
$2.1-$ \\
5.2 \\
\end{tabular} & $\begin{array}{l}1.5- \\
1.8 \\
\end{array}$ & $\begin{array}{l}0.6- \\
0.8\end{array}$ & $\begin{array}{l}-2.25-(- \\
4.91)\end{array}$ & TAM 111 & $\underline{T} / \mathrm{C}$ & $\underline{\mathrm{A}} / \mathrm{C}$ & & $\mathrm{Dh}$ \\
\hline $\begin{array}{l}\text { Qtw.tamu.1 } \\
\text { D.375 }\end{array}$ & $1 \mathrm{D}$ & 375.4 & \begin{tabular}{|l|}
$\mathrm{T}$ \\
$\mathrm{W}$ \\
\end{tabular} & 12EP3, across all env & $1 \mathrm{D}$ & 46 & $\begin{array}{l}45.5- \\
46.5\end{array}$ & \begin{tabular}{|l|}
$4.9-$ \\
16.9 \\
\end{tabular} & 9.6 & 7.2 & \begin{tabular}{|l|}
$2.2-$ \\
11.9 \\
\end{tabular} & 1.3 & 0.9 & $\begin{array}{l}2.07- \\
6.13 \\
\end{array}$ & TAM 112 & $\mathrm{~A} / \underline{\mathrm{C}}$ & $\underline{\mathrm{A}} / \mathrm{G}$ & & Jin \\
\hline $\begin{array}{l}\text { Qtw.tamu.1 } \\
\text { D.422 }\end{array}$ & $1 \mathrm{D}$ & 421.8 & \begin{tabular}{|l|}
$\mathrm{T}$ \\
$\mathrm{W}$ \\
\end{tabular} & $\begin{array}{l}\text { 12CH, across all env, AcrossME2, ME2, } \\
\text { Across ME12 }\end{array}$ & $1 \mathrm{D}$ & 69 & $\begin{array}{l}68.5- \\
69.5 \\
\end{array}$ & $\begin{array}{l}3.5- \\
20.1\end{array}$ & $\begin{array}{l}5.1- \\
11.4\end{array}$ & $\begin{array}{l}0.1- \\
9.4\end{array}$ & $\begin{array}{l}2.7- \\
11.0\end{array}$ & $\begin{array}{l}1.4- \\
10.2\end{array}$ & $\begin{array}{l}0.2- \\
1.3\end{array}$ & $\begin{array}{l}2.19- \\
6.41\end{array}$ & TAM 112 & $\mathrm{~T} / \underline{\mathrm{C}}$ & $\underline{\mathrm{C}} / \mathrm{A}$ & $\mathrm{y}$ & \\
\hline $\begin{array}{l}\text { Qtw.tamu.2 } \\
\text { B.709 }\end{array}$ & 2B & 708.7 & \begin{tabular}{|l|}
$T$ \\
$W$
\end{tabular} & 13EP5, across all env, AcrossME2 & $2 \mathrm{~B}$ & 124 & $\begin{array}{l}123.5- \\
124.5\end{array}$ & $\begin{array}{l}7.3- \\
20.3\end{array}$ & $\begin{array}{l}11.3- \\
12.3\end{array}$ & $\begin{array}{l}6.0- \\
8.1\end{array}$ & $\begin{array}{l}2.2- \\
10.1\end{array}$ & $\begin{array}{l}1.6- \\
2.8\end{array}$ & $\begin{array}{l}0.6- \\
0.7\end{array}$ & $\begin{array}{l}2.36- \\
6.91\end{array}$ & TAM 112 & $\mathrm{~T} / \mathrm{G}$ & G/A & & \\
\hline $\begin{array}{l}\text { Qtw.tamu.2 } \\
.487\end{array}$ & $2 \mathrm{D}$ & 486.8 & \begin{tabular}{|l|}
$\mathrm{T}$ \\
$\mathrm{W}$ \\
\end{tabular} & across all env, AcrossME2 & $2 \mathrm{D}$ & 104 & $\begin{array}{l}102.5- \\
104.5 \\
\end{array}$ & $\begin{array}{l}13.8- \\
19.4\end{array}$ & $\begin{array}{l}8.9- \\
12.2\end{array}$ & \begin{tabular}{ll|}
$4.9-$ \\
7.3 \\
\end{tabular} & $\begin{array}{l}2.2- \\
2.9\end{array}$ & $\begin{array}{l}1.6- \\
2.2\end{array}$ & $\begin{array}{ll}0.6- \\
0.7\end{array}$ & $\begin{array}{l}2.33- \\
2.47\end{array}$ & TAM 112 & $\underline{G} / \mathrm{C}$ & $\mathrm{C} / \underline{\mathrm{A}}$ & & h \\
\hline
\end{tabular}




\begin{tabular}{|c|c|c|c|c|c|c|c|c|c|c|c|c|c|c|c|c|c|c|c|}
\hline $\begin{array}{l}\text { Qtw.tamu.3 } \\
\text { B.507 }\end{array}$ & 3B & 507.0 & $\begin{array}{l}\mathrm{T} \\
\mathrm{W} \\
\end{array}$ & $12 \mathrm{CH}$, across all env, AcrossME2 & $3 \mathrm{~B}$ & 27 & $\begin{array}{l}24.5- \\
27.5\end{array}$ & $\begin{array}{l}4.6- \\
13.8\end{array}$ & $\begin{array}{l}8.2- \\
8.3\end{array}$ & $\begin{array}{l}3.9- \\
5.5\end{array}$ & $\begin{array}{l}1.6- \\
6.6\end{array}$ & \begin{tabular}{|l|}
$1.1-$ \\
2.0
\end{tabular} & \begin{tabular}{|l|}
$0.6-$ \\
0.8 \\
\end{tabular} & \begin{tabular}{|l|}
$-1.92-(-$ \\
$5.24)$
\end{tabular} & TAM 111 & $\mathrm{G} / \underline{\mathrm{C}}$ & $\underline{T} / \mathrm{C}$ & & \\
\hline $\begin{array}{l}\text { Qtw.tamu.3 } \\
\text { D.549 }\end{array}$ & 3D & 548.6 & $\begin{array}{l}\mathrm{T} \\
\mathrm{W} \\
\end{array}$ & across all env, AcrossME2 & 3D & 53 & $\begin{array}{l}49.5- \\
53.5\end{array}$ & $\begin{array}{l}9.3- \\
15.6\end{array}$ & $\begin{array}{l}7.1- \\
12.9\end{array}$ & $\begin{array}{l}2.2- \\
2.8\end{array}$ & $\begin{array}{l}2.0- \\
2.1 \\
\end{array}$ & \begin{tabular}{|l|}
$1.67-$ \\
1.74 \\
\end{tabular} & \begin{tabular}{|l|}
$0.3-$ \\
0.4 \\
\end{tabular} & $\begin{array}{l}-2.21-(- \\
2.39)\end{array}$ & TAM 111 & $\mathrm{~A} / \underline{\mathrm{G}}$ & $\mathrm{T} / \underline{\mathrm{C}}$ & & \\
\hline $\begin{array}{l}\text { Qtw.tamu.3 } \\
\text { D.555 }\end{array}$ & 3D & 554.7 & \begin{tabular}{|l|}
$\mathrm{T}$ \\
$\mathrm{W}$ \\
\end{tabular} & across all env, AcrossME2 & $3 \mathrm{D}$ & 58 & \begin{tabular}{|l|}
$57.5-$ \\
58.5
\end{tabular} & $\begin{array}{l}11.0- \\
16.6\end{array}$ & $\begin{array}{l}9.4- \\
14.6\end{array}$ & $\begin{array}{l}1.6- \\
2.0\end{array}$ & $\begin{array}{l}2.3- \\
2.7\end{array}$ & \begin{tabular}{|l|}
$1.9-$ \\
2.3 \\
\end{tabular} & \begin{tabular}{|l|}
$0.37-$ \\
0.43 \\
\end{tabular} & $\begin{array}{l}-2.55-(- \\
2.57)\end{array}$ & TAM 111 & $\mathrm{C} / \underline{\mathrm{T}}$ & $\mathrm{A} / \underline{\mathrm{C}}$ & & \\
\hline $\begin{array}{l}\text { Qtw.tamu.3 } \\
\text { D.563 }\end{array}$ & $3 \mathrm{D}$ & 562.7 & \begin{tabular}{|l|}
$\mathrm{T}$ \\
$\mathrm{W}$ \\
\end{tabular} & across all env, AcrossME2 & $3 \mathrm{D}$ & 63 & \begin{tabular}{|l|}
$62.5-$ \\
63.5 \\
\end{tabular} & \begin{tabular}{|l}
$10.6-$ \\
14.0
\end{tabular} & $\begin{array}{l}9.7- \\
12.3 \\
\end{array}$ & $\begin{array}{l}1.0- \\
1.8 \\
\end{array}$ & $\begin{array}{l}2.0- \\
2.9 \\
\end{array}$ & \begin{tabular}{|l|}
$1.6-$ \\
2.3 \\
\end{tabular} & \begin{tabular}{|l|}
$0.4-$ \\
0.6 \\
\end{tabular} & \begin{tabular}{|l|}
$-2.35-(-$ \\
$2.57)$
\end{tabular} & TAM 111 & $\mathrm{~T} / \underline{\mathrm{C}}$ & $\mathrm{T} / \underline{\mathrm{G}}$ & & \\
\hline $\begin{array}{l}\text { Qtw.tamu.4 } \\
\text { D.29 }\end{array}$ & $4 \mathrm{D}$ & 29.0 & \begin{tabular}{|l|}
$\mathrm{T}$ \\
$\mathrm{W}$ \\
\end{tabular} & 12UV7, AcrossME1 & $4 \mathrm{D}$ & 6 & $\begin{array}{l}4.5- \\
8.5 \\
\end{array}$ & \begin{tabular}{|l|}
$5.6-$ \\
7.1 \\
\end{tabular} & 3.0 & 4.1 & $\begin{array}{l}2.5- \\
5.0\end{array}$ & 2.0 & 3.1 & \begin{tabular}{|l|}
$1.95-$ \\
7.66 \\
\end{tabular} & TAM 112 & $\underline{\mathrm{A}} / \mathrm{G}$ & $\mathrm{G} / \underline{\mathrm{T}}$ & & $\mathrm{Ya}$ \\
\hline $\begin{array}{l}\text { Qtw.tamu.4 } \\
.63\end{array}$ & $4 \mathrm{D}$ & 62.8 & $\begin{array}{l}\mathrm{T} \\
\mathrm{W}\end{array}$ & $\begin{array}{l}\text { 12BD, 12EP1, 12EP3, 13EP2, 14CH, across } \\
\text { all env, AcrossME2 }\end{array}$ & 4D & 11 & $\begin{array}{l}10.5- \\
11.5\end{array}$ & $\begin{array}{l}3.9- \\
35.6\end{array}$ & $\begin{array}{l}14.6- \\
18.6\end{array}$ & $\begin{array}{l}10.4- \\
17.0\end{array}$ & $\begin{array}{l}5.6- \\
16.3\end{array}$ & $\begin{array}{l}2.4- \\
3.6\end{array}$ & $\begin{array}{l}3.2- \\
4.3\end{array}$ & $\begin{array}{l}2.89- \\
10.35\end{array}$ & TAM 112 & $\underline{\mathrm{C}} / \mathrm{T}$ & $\underline{\mathrm{C}} / \mathrm{T}$ & & \\
\hline $\begin{array}{l}\text { Qtw.tamu.4 } \\
\text { D.110 }\end{array}$ & $4 \mathrm{D}$ & 109.8 & $\begin{array}{l}\mathrm{T} \\
\mathrm{W} \\
\end{array}$ & 12UV5, 13EP3, across all env, AcrossME1 & $4 \mathrm{D}$ & 13 & $\begin{array}{ll}12.5- \\
13.5\end{array}$ & $\begin{array}{l}3.5- \\
14.9\end{array}$ & $\begin{array}{l}4.8- \\
5.7 \\
\end{array}$ & $\begin{array}{l}5.8- \\
10.0 \\
\end{array}$ & $\begin{array}{l}2.4- \\
19.4\end{array}$ & $\begin{array}{l}0.6- \\
3.8 \\
\end{array}$ & $\begin{array}{l}1.8- \\
5.5 \\
\end{array}$ & $\begin{array}{l}1.47- \\
8.01 \\
\end{array}$ & TAM 112 & $\mathrm{C} / \underline{\mathrm{T}}$ & $\underline{\mathrm{T}} / \mathrm{C}$ & $y$ & \\
\hline $\begin{array}{l}\text { Qtw.tamu.5 } \\
\text { A.74 }\end{array}$ & $5 \mathrm{~A}$ & 73.8 & \begin{tabular}{|l|l}
$\mathrm{T}$ \\
$\mathrm{W}$ \\
\end{tabular} & across all env, AcrossME2 & $5 \mathrm{~A}$ & 40 & $\begin{array}{l}39.5- \\
40.5\end{array}$ & $\begin{array}{ll}10.1- \\
14.4\end{array}$ & $\begin{array}{l}6.0- \\
9.4 \\
\end{array}$ & $\begin{array}{ll}4.1- \\
5.0\end{array}$ & $\begin{array}{l}1.6- \\
2.2\end{array}$ & $\begin{array}{l}1.2- \\
1.5 \\
\end{array}$ & \begin{tabular}{|l|}
$0.4-$ \\
0.7 \\
\end{tabular} & $\begin{array}{l}2.02- \\
2.05\end{array}$ & TAM 112 & $\mathrm{~T} / \underline{\mathrm{C}}$ & $\underline{\mathrm{G}} / \mathrm{A}$ & & \\
\hline $\begin{array}{l}\text { Qtw.tamu.5 } \\
\text { A.157 }\end{array}$ & $5 \mathrm{~A}$ & 157.3 & \begin{tabular}{l|l}
$\mathrm{T}$ \\
$\mathrm{W}$ \\
\end{tabular} & across all env, AcrossME2 & $5 \mathrm{~A}$ & 43 & $\begin{array}{l}42.5- \\
43.5\end{array}$ & $\begin{array}{l}10.1- \\
13.5\end{array}$ & $\begin{array}{l}6.0- \\
8.7\end{array}$ & \begin{tabular}{|l|}
$4.1-$ \\
4.8
\end{tabular} & $\begin{array}{l}1.5- \\
2.2\end{array}$ & \begin{tabular}{|l|}
$1.1-$ \\
1.5 \\
\end{tabular} & \begin{tabular}{|l|}
$0.4-$ \\
0.7 \\
\end{tabular} & $\begin{array}{l}1.97- \\
2.03\end{array}$ & TAM 112 & $\mathrm{G} / \underline{\mathrm{C}}$ & $\underline{\mathrm{G}} / \mathrm{A}$ & & \\
\hline $\begin{array}{l}\text { Qtw.tamu.5 } \\
\text { A.702 }\end{array}$ & $5 \mathrm{~A}$ & 702.0 & $\begin{array}{l}\mathrm{T} \\
\mathrm{W}\end{array}$ & across all env, AcrossME1 & $5 \mathrm{~A}$ & 194 & \begin{tabular}{|l|}
$192.5-$ \\
194.5
\end{tabular} & $\begin{array}{l}6.8- \\
14.5\end{array}$ & $\begin{array}{l}5.5- \\
11.1\end{array}$ & $\begin{array}{l}1.3- \\
3.4\end{array}$ & $\begin{array}{l}1.7- \\
4.0\end{array}$ & \begin{tabular}{|l|}
$1.4-$ \\
3.6
\end{tabular} & \begin{tabular}{|l|}
$0.2-$ \\
0.4 \\
\end{tabular} & $\begin{array}{l}2.22- \\
2.66\end{array}$ & TAM 112 & $\mathrm{~A} / \underline{\mathrm{G}}$ & $\mathrm{T} / \underline{\mathrm{C}}$ & & \\
\hline $\begin{array}{l}\text { Qtw.tamu.5 } \\
\text { B.589 }\end{array}$ & $5 \mathrm{~B}$ & 589.4 & \begin{tabular}{|l|}
$\mathrm{T}$ \\
$\mathrm{W}$ \\
\end{tabular} & across all env, AcrossME1, AcrossME2 & 5B & 75 & $\begin{array}{l}74.5- \\
75.5 \\
\end{array}$ & \begin{tabular}{|l|}
$6.8-$ \\
16.6 \\
\end{tabular} & \begin{tabular}{|l|}
$5.8-$ \\
13.4 \\
\end{tabular} & \begin{tabular}{|l|}
$1.0-$ \\
3.2 \\
\end{tabular} & $\begin{array}{l}2.3- \\
4.4 \\
\end{array}$ & \begin{tabular}{|l|}
$1.7-$ \\
3.8 \\
\end{tabular} & \begin{tabular}{|l|}
$0.6-$ \\
0.8 \\
\end{tabular} & \begin{tabular}{|l|}
$-2.28-(-$ \\
$2.71)$ \\
\end{tabular} & TAM 111 & $\underline{\mathrm{A}} / \mathrm{G}$ & $\underline{\mathrm{C} / \mathrm{T}}$ & & $\mathrm{Zh}$ \\
\hline $\begin{array}{l}\text { Qtw.tamu.5 } \\
\text { B.646 }\end{array}$ & $5 \mathrm{~B}$ & 646.0 & $\begin{array}{l}\mathrm{T} \\
\mathrm{W} \\
\end{array}$ & across all env, AcrossME2 & $5 B$ & 94 & \begin{tabular}{|l|}
$90.5-$ \\
94.5
\end{tabular} & $\begin{array}{l}9.9- \\
14.4\end{array}$ & $\begin{array}{l}8.2- \\
11.2\end{array}$ & \begin{tabular}{|l|}
$1.7-$ \\
3.2
\end{tabular} & $\begin{array}{l}2.0- \\
2.7\end{array}$ & \begin{tabular}{|l|}
$1.4-$ \\
2.0
\end{tabular} & \begin{tabular}{|l|}
$0.5-$ \\
0.7 \\
\end{tabular} & \begin{tabular}{|l|}
$-2.23-(-$ \\
$2.36)$
\end{tabular} & TAM 111 & $\underline{\mathrm{A}} / \mathrm{G}$ & $\mathrm{T} / \mathrm{C}$ & & \\
\hline $\begin{array}{l}\text { Qtw.tamu.6 } \\
\text { A.7 }\end{array}$ & $6 \mathrm{~A}$ & 7.2 & $\begin{array}{l}\mathrm{T} \\
\mathrm{W} \\
\end{array}$ & across all env, AcrossME2 & $6 \mathrm{~A}$ & 12 & $\begin{array}{l}11.5- \\
12.5 \\
\end{array}$ & $\begin{array}{l}9.2- \\
15.0\end{array}$ & $\begin{array}{l}6.0- \\
11.4 \\
\end{array}$ & $\begin{array}{l}3.2- \\
3.5 \\
\end{array}$ & $\begin{array}{l}2.1- \\
2.2 \\
\end{array}$ & \begin{tabular}{|l}
$1.47-$ \\
1.49 \\
\end{tabular} & \begin{tabular}{|l|}
$0.6-$ \\
0.8 \\
\end{tabular} & \begin{tabular}{|l|}
$2.03-$ \\
2.26 \\
\end{tabular} & TAM 112 & $\underline{\mathrm{T}} / \mathrm{C}$ & $\underline{\mathrm{T}} / \mathrm{C}$ & & \\
\hline $\begin{array}{l}\text { Qtw.tamu. } 6 \\
\text { A.12 }\end{array}$ & $6 \mathrm{~A}$ & 12.4 & \begin{tabular}{|l|}
$\mathrm{T}$ \\
$\mathrm{W}$ \\
\end{tabular} & 12BD, across all env, AcrossME1 & $6 \mathrm{~A}$ & 20 & $\begin{array}{l}19.5- \\
20.5\end{array}$ & $\begin{array}{l}4.1- \\
17.9\end{array}$ & $\begin{array}{l}9.5- \\
12.1\end{array}$ & $\begin{array}{l}2.2- \\
5.8\end{array}$ & $\begin{array}{l}2.0- \\
8.5\end{array}$ & $\begin{array}{l}1.6- \\
6.2 \\
\end{array}$ & \begin{tabular}{|l|}
$0.2-$ \\
0.4 \\
\end{tabular} & $\begin{array}{l}2.32- \\
3.58\end{array}$ & TAM 112 & $\mathrm{G} / \underline{\mathrm{C}}$ & $\mathrm{T} / \underline{\mathrm{G}}$ & $\mathrm{y}$ & \\
\hline $\begin{array}{l}\text { Qtw.tamu.6 } \\
\text { A.603 }\end{array}$ & $6 \mathrm{~A}$ & 603.3 & \begin{tabular}{|l}
$\mathrm{T}$ \\
$\mathrm{W}$ \\
\end{tabular} & 12UV7, across all env, AcrossME1 & $6 \mathrm{~A}$ & 134 & $\begin{array}{l}133.5- \\
134.5\end{array}$ & $\begin{array}{l}20.0- \\
24.4\end{array}$ & $\begin{array}{l}0.0- \\
1.6 \\
\end{array}$ & $\begin{array}{l}20.3- \\
24.4 \\
\end{array}$ & $\begin{array}{l}4.8- \\
21.4\end{array}$ & $\begin{array}{l}0.0- \\
1.1 \\
\end{array}$ & \begin{tabular}{|l|}
$4.8-$ \\
20.3 \\
\end{tabular} & \begin{tabular}{|l|}
$-0.08-$ \\
16.58 \\
\end{tabular} & $\begin{array}{l}\text { TAM 111, } \\
\text { TAM } 112 \\
\end{array}$ & $\mathrm{~A} / \underline{\mathrm{G}}$ & $\underline{\mathrm{T}} / \mathrm{C}$ & & \\
\hline $\begin{array}{l}\text { Qtw.tamu.6 } \\
\text { A.609 }\end{array}$ & $6 \mathrm{~A}$ & 608.5 & \begin{tabular}{|l|}
$\mathrm{T}$ \\
$\mathrm{W}$ \\
\end{tabular} & 13EP5, across all env, AcrossME2 & $6 \mathrm{~A}$ & 139 & \begin{tabular}{|l|}
$138.5-$ \\
139.5 \\
\end{tabular} & \begin{tabular}{|l|}
$4.6-$ \\
14.0 \\
\end{tabular} & $\begin{array}{l}6.7- \\
8.6 \\
\end{array}$ & \begin{tabular}{|l|}
$3.9-$ \\
5.3 \\
\end{tabular} & $\begin{array}{l}1.7- \\
5.8 \\
\end{array}$ & \begin{tabular}{|l|}
$1.1-$ \\
1.6 \\
\end{tabular} & \begin{tabular}{|l|}
$0.6-$ \\
0.8 \\
\end{tabular} & \begin{tabular}{|l|}
$-5.19-(-$ \\
$1.96)$ \\
\end{tabular} & TAM 111 & $\underline{\mathrm{T}} / \mathrm{C}$ & $\underline{\mathrm{T}} / \mathrm{C}$ & & \\
\hline $\begin{array}{l}\text { Qtw.tamu.6 } \\
\text { A.612 }\end{array}$ & $6 \mathrm{~A}$ & 611.6 & \begin{tabular}{|l|}
$\mathrm{T}$ \\
$\mathrm{W}$ \\
\end{tabular} & $12 \mathrm{CH}$, across all env, AcrossME2 & $6 \mathrm{~A}$ & 143 & $\begin{array}{l}142.5- \\
143.5\end{array}$ & $\begin{array}{l}6.6- \\
14.4\end{array}$ & $\begin{array}{l}5.9- \\
7.7\end{array}$ & \begin{tabular}{|l|}
$5.5-$ \\
6.8 \\
\end{tabular} & $\begin{array}{l}1.8- \\
10.1\end{array}$ & $\begin{array}{l}1.0- \\
1.4 \\
\end{array}$ & \begin{tabular}{|l|}
$0.8-$ \\
1.2 \\
\end{tabular} & \begin{tabular}{|l|}
$-1.85-(-$ \\
$6.47)$
\end{tabular} & TAM 111 & $\mathrm{~A} / \underline{\mathrm{G}}$ & $\mathrm{T} / \underline{\mathrm{C}}$ & & \\
\hline $\begin{array}{l}\text { Qtw.tamu.6 } \\
\text { B.130 }\end{array}$ & 6B & 130.3 & $\begin{array}{l}\mathrm{T} \\
\mathrm{W} \\
\end{array}$ & 12UVL, 14EP4, across all env, AcrossME1 & \begin{tabular}{|l|}
$6 \mathrm{~B}$ \\
2 \\
\end{tabular} & 1 & $0-2.5$ & $\begin{array}{l}5.0- \\
15.1 \\
\end{array}$ & $\begin{array}{l}5.8- \\
6.1 \\
\end{array}$ & \begin{tabular}{|l|}
$5.6-$ \\
9.3 \\
\end{tabular} & $\begin{array}{l}2.4- \\
17.6\end{array}$ & $\begin{array}{l}0.8- \\
4.2 \\
\end{array}$ & \begin{tabular}{|l|}
$1.6-$ \\
4.5 \\
\end{tabular} & $\begin{array}{l}1.64- \\
7.88\end{array}$ & TAM 112 & $\mathrm{~T} / \underline{\mathrm{G}}$ & $\mathrm{A} / \underline{\mathrm{C}}$ & & $\mathrm{Ju}$ \\
\hline Qtw.tamu.6 & 6B & 466.0 & $\mathrm{~T}$ & 11EP5, 12BD, 13EP2, 14CH, 17BD, across all & $6 \mathrm{~B}$ & 7 & $6.5-$ & $3.8-$ & 3.4- & $2.4-$ & $3.4-$ & $1.5-$ & $2.0-$ & $2.28-$ & TAM 112 & $\underline{\mathrm{G}} / \mathrm{A}$ & $\underline{\mathrm{A}} / \mathrm{G}$ & & \\
\hline
\end{tabular}




\begin{tabular}{|c|c|c|c|c|c|c|c|c|c|c|c|c|c|c|c|c|c|c|c|}
\hline B.466 & & & $\mathrm{W}$ & env, AcrossME1, ME1, Across ME12 & 2 & & 7.5 & 23.9 & 11.4 & 12.5 & 15.4 & 6.8 & 6.4 & 7.77 & & & & & \\
\hline $\begin{array}{l}\text { Qtw.tamu.6 } \\
\text { B.559 }\end{array}$ & $6 \mathrm{~B}$ & 559.4 & $\begin{array}{l}\mathrm{T} \\
\mathrm{W}\end{array}$ & 13EP5, AcrossME2, ME2, Across ME12 & $\begin{array}{l}6 \mathrm{~B} \\
2 \\
\end{array}$ & 8 & $\begin{array}{l}7.5- \\
8.5\end{array}$ & $\begin{array}{l}4.1- \\
15.2\end{array}$ & $\begin{array}{l}2.4- \\
5.0\end{array}$ & $\begin{array}{l}1.7- \\
10.2\end{array}$ & \begin{tabular}{|l|}
$3.7-$ \\
15.4
\end{tabular} & $\begin{array}{l}1.2- \\
4.8\end{array}$ & $\begin{array}{l}2.5- \\
3.4\end{array}$ & $\begin{array}{l}1.86- \\
8.55\end{array}$ & TAM 112 & $\mathrm{~A} / \underline{\mathrm{G}}$ & $\mathrm{T} / \mathrm{C}$ & & Jul \\
\hline $\begin{array}{l}\text { Qtw.tamu.6 } \\
\text { D.459 }\end{array}$ & $6 \mathrm{D}$ & 459.2 & \begin{tabular}{|l}
$T$ \\
$W$ \\
\end{tabular} & $\begin{array}{l}\text { 12UV5, across all env, across all env, } \\
\text { AcrossME1, AcrossME2, ME1 }\end{array}$ & $6 \mathrm{D}$ & 99 & $\begin{array}{l}98.5- \\
99.5\end{array}$ & \begin{tabular}{|l|}
$4.0-$ \\
21.3
\end{tabular} & $\begin{array}{l}10.1- \\
15.8\end{array}$ & $1.8-$ & \begin{tabular}{l|}
$2.1-$ \\
11.3 \\
\end{tabular} & $\begin{array}{l}1.4- \\
6.9 \\
\end{array}$ & $\begin{array}{l}0.5- \\
2.7\end{array}$ & \begin{tabular}{|l|}
$-2.21-(-$ \\
$7.23)$ \\
\end{tabular} & TAM 111 & $\mathrm{~A} / \underline{\mathrm{G}}$ & $\mathrm{A} / \underline{\mathrm{G}}$ & & Ya \\
\hline $\begin{array}{l}\text { Qtw.tamu.7 } \\
\text { B.9 }\end{array}$ & $7 \mathrm{~B}$ & 8.5 & $\begin{array}{l}\mathrm{T} \\
\mathrm{W}\end{array}$ & $12 \mathrm{CH}$, across all env, AcrossME2 & \begin{tabular}{|l|}
$7 \mathrm{~B}$ \\
1
\end{tabular} & 19 & \begin{tabular}{|l|}
$17.5-$ \\
21.5
\end{tabular} & \begin{tabular}{|l|}
$3.5-$ \\
17.3
\end{tabular} & $\begin{array}{l}7.5- \\
9.5\end{array}$ & $\begin{array}{l}5.5- \\
9.8\end{array}$ & $\begin{array}{l}1.9- \\
5.4\end{array}$ & $\begin{array}{l}1.0- \\
2.2\end{array}$ & $\begin{array}{l}0.8- \\
0.9\end{array}$ & \begin{tabular}{|l|}
$-1.86-(-$ \\
$4.78)$
\end{tabular} & TAM 111 & $\underline{\mathrm{A}} / \mathrm{C}$ & $\underline{\mathrm{A}} / \mathrm{C}$ & & Jul \\
\hline $\begin{array}{l}\text { Qtw.tamu.7 } \\
\text { B.64 }\end{array}$ & 7B & 64.5 & $\begin{array}{l}\mathrm{T} \\
\mathrm{W} \\
\end{array}$ & across all env, AcrossME2 & \begin{tabular}{|l|}
$7 \mathrm{~B}$ \\
1 \\
\end{tabular} & 48 & $\begin{array}{l}47.5- \\
48.5 \\
\end{array}$ & \begin{tabular}{|l|}
$9.2-$ \\
13.0
\end{tabular} & $\begin{array}{l}7.2- \\
9.5\end{array}$ & $\begin{array}{l}2.1- \\
3.6\end{array}$ & $\begin{array}{l}1.7- \\
2.3\end{array}$ & \begin{tabular}{|l|}
$1.2-$ \\
1.7
\end{tabular} & $\begin{array}{l}0.46- \\
0.55\end{array}$ & $\begin{array}{l}-2.05-(- \\
2.21)\end{array}$ & TAM 111 & $\mathrm{G} / \mathrm{A}$ & $\mathrm{C} / \underline{\mathrm{T}}$ & & \\
\hline $\begin{array}{l}\text { Qtw.tamu.7 } \\
\text { D.61 }\end{array}$ & 7D & 60.6 & $\begin{array}{l}\mathrm{T} \\
\mathrm{W} \\
\end{array}$ & $11 \mathrm{EP} 5,12 \mathrm{CH}$, across all env, AcrossME2 & 7D & 79 & \begin{tabular}{|l|}
$78.5-$ \\
79.5 \\
\end{tabular} & \begin{tabular}{|l|}
$6.9-$ \\
27.0
\end{tabular} & $\begin{array}{l}11.2- \\
12.4\end{array}$ & $\begin{array}{l}12.4- \\
15.8\end{array}$ & $\begin{array}{l}3.3- \\
21.6\end{array}$ & $\begin{array}{l}1.5- \\
3.1 \\
\end{array}$ & $\begin{array}{l}1.8- \\
2.8\end{array}$ & $\begin{array}{l}2.25- \\
8.48\end{array}$ & TAM 112 & $\mathrm{~T} / \mathrm{C}$ & $\mathrm{C} / \underline{\mathrm{T}}$ & $\mathrm{y}$ & \\
\hline $\begin{array}{l}\text { Qtw.tamu.7 } \\
\text { D.604 }\end{array}$ & 7D & 604.0 & \begin{tabular}{|l|}
$\mathrm{T}$ \\
$\mathrm{W}$ \\
\end{tabular} & 13EP5, across all env, AcrossME2 & $7 \mathrm{D}$ & 206 & $\begin{array}{l}204.5- \\
206.5\end{array}$ & \begin{tabular}{|l|}
$5.2-$ \\
15.3 \\
\end{tabular} & \begin{tabular}{|l|}
$5.3-$ \\
8.8 \\
\end{tabular} & \begin{tabular}{|l|}
$5.4-$ \\
6.4 \\
\end{tabular} & \begin{tabular}{|l|}
$1.7-$ \\
6.8 \\
\end{tabular} & \begin{tabular}{|l|}
$1.1-$ \\
1.3 \\
\end{tabular} & $\begin{array}{l}0.5- \\
0.8 \\
\end{array}$ & \begin{tabular}{|l|}
$1.91-(-$ \\
$5.61)$ \\
\end{tabular} & TAM 111 & & $\mathrm{G} / \underline{\mathrm{A}}$ & & \\
\hline $\begin{array}{l}\text { Qht.tamu.4 } \\
\text { D.21 }\end{array}$ & $4 \mathrm{D}$ & 20.6 & \begin{tabular}{|l}
$\mathrm{H}$ \\
$\mathrm{T}$ \\
\end{tabular} & 12BD, DRY, across all env & $4 \mathrm{D}$ & 0 & $0-0.5$ & \begin{tabular}{|l|}
$3.7-$ \\
8.8 \\
\end{tabular} & 1.2 & 7.6 & $\begin{array}{l}4.9- \\
6.7 \\
\end{array}$ & 1.2 & 3.7 & \begin{tabular}{|l|}
$0.21-$ \\
0.47 \\
\end{tabular} & TAM 112 & $\underline{\mathrm{A}} / \mathrm{G}$ & $\underline{\mathrm{T}} / \mathrm{C}$ & y & \\
\hline $\begin{array}{l}\text { Qht.tamu.7 } \\
\text { D.61 }\end{array}$ & 7D & 60.6 & $\begin{array}{l}\mathrm{H} \\
\mathrm{T} \\
\end{array}$ & $17 \mathrm{EI}$ & $7 \mathrm{D}$ & 79 & \begin{tabular}{|l|}
$77.5-$ \\
80.5
\end{tabular} & 3.3 & & & 8.1 & & & -1.05 & TAM 111 & $\mathrm{~T} / \mathrm{C}$ & $\mathrm{C} / \underline{\mathrm{T}}$ & $\mathrm{y}$ & \\
\hline $\begin{array}{l}\text { Qht.tamu.7 } \\
\text { D.64 }\end{array}$ & 7D & 64.3 & \begin{tabular}{|l}
$\mathrm{H}$ \\
$\mathrm{T}$ \\
\end{tabular} & 11EP5, across all env & $7 \mathrm{D}$ & 80 & \begin{tabular}{|l|}
$78.5-$ \\
80.5 \\
\end{tabular} & \begin{tabular}{|l|}
$3.8-$ \\
13.2 \\
\end{tabular} & 2.0 & 5.0 & $\begin{array}{l}13.5- \\
19.6 \\
\end{array}$ & 3.5 & 4.4 & \begin{tabular}{|l|}
$-0.41-(-$ \\
$1.63)$ \\
\end{tabular} & TAM 111 & $\underline{\mathrm{T}} / \mathrm{C}$ & $\mathrm{C} / \underline{\mathrm{T}}$ & $\mathrm{y}$ & \\
\hline $\begin{array}{l}\text { Qhd.tamu.1 } \\
\text { A.12 }\end{array}$ & $1 \mathrm{~A}$ & 11.8 & $\begin{array}{l}\mathrm{H} \\
\mathrm{D} \\
\end{array}$ & across all env & $1 \mathrm{~A}$ & 9 & \begin{tabular}{|l|}
$7.5-$ \\
9.5 \\
\end{tabular} & 8.6 & 5.6 & 2.9 & 3.1 & 2.1 & 1.0 & 0.28 & TAM 112 & $\underline{\mathrm{A} / \mathrm{G}}$ & $\mathrm{A} / \underline{\mathrm{G}}$ & $y$ & \\
\hline $\begin{array}{l}\text { Qhd.tamu.4 } \\
\text { B.659 }\end{array}$ & $4 \mathrm{~B}$ & 659.2 & $\begin{array}{l}\mathrm{H} \\
\mathrm{D}\end{array}$ & 11EP2, across all env & $4 \mathrm{~B}$ & 94 & $\begin{array}{l}93.5- \\
94.5 \\
\end{array}$ & \begin{tabular}{|l|l|}
$6.7-$ \\
12.4 \\
\end{tabular} & 7.9 & 4.5 & \begin{tabular}{|l|}
$7.2-$ \\
18.3
\end{tabular} & 3.0 & 4.3 & \begin{tabular}{|l|}
$0.34-$ \\
1.53 \\
\end{tabular} & TAM 112 & $\underline{\mathrm{A}} / \mathrm{G}$ & $\underline{\mathrm{A}} / \mathrm{G}$ & $y$ & \\
\hline $\begin{array}{l}\text { Qhd.tamu.7 } \\
\text { B.16 }\end{array}$ & $7 \mathrm{~B}$ & 15.6 & $\begin{array}{l}\mathrm{H} \\
\mathrm{D}\end{array}$ & across all env & \begin{tabular}{|l|}
$7 \mathrm{~B}$ \\
1
\end{tabular} & 24 & $\begin{array}{l}21.5- \\
24.5\end{array}$ & 8.7 & 4.4 & 4.4 & 2.2 & 1.6 & 0.6 & 0.25 & TAM 112 & $\underline{\mathrm{A}} / \mathrm{C}$ & $\mathrm{T} / \mathrm{C}$ & . & \\
\hline
\end{tabular}

4 a Physical position based on IWGSC RefSeq v 1.0 Mega base pair position.

b Trait abbreviations: grain yield (YLD), test weight (TW), days to heading (HD), and plant height (HT).

c Abbreviations: 11, Year 2011; 12, Year 2012; 13, Year 2013; 14, Year 2014; 17, Year 2017; BD, Bushland dry (I0), TX;

BI, Bushland Irrigated (I100), TX; CH, Chillicothe (I0), TX; CVI, Clovis Irrigated (I100), NM; EP1, Etter (I0), TX; EP2, Etter (I50), TX;

EP3, Etter (I65), TX; EP4, Etter (I75), TX; EP5, Etter (100), TX; UVD, Uvalde dry (I0), TX; UV5, Uvalde (I50), TX; UV7, Uvalde (I70),

TX; UVL, Uvalde (I100), TX.

Ind Env-ADD, single environment QTL analysis; Multi Env-ADD, single trait multiple environment QTL analysis; Ind ME-ADD,

Individual mega environment QTL analysis; Across ME-ADD, single trait multiple mega environment QTL analysis.

Environment 1 to 28 for yield are: 11BD, 11CH, 11EP1, 11EP2, 11EP3, 11EP4, 11EP5, 12BD, 12CH, 12EP1, 12EP2, 12EP3, 12UV5, 12UV7, 12UVL, 12UVD,

13EP2, 13EP3, 13EP4, 13EP5, 13UVL, 14CH, 14EP4, 14EP5, 17BD, 17BI, 17CVI, and 17EI.

Environment 1 to 19 for test weight are: 11EP5, 12BD, 12CH, 12EP1, 12EP2, 12EP3, 12UV7, 12UVL, 12UV5, 13EP2, 13EP3, 13EP4, 13EP5, 14CH,

14EP4, 14EP5, 17BD, 17BI, and 17EI. 
16 Environment 1 to 11 for height are: 11BD, 11EP1, 11EP2, 11EP3, 11EP4, 11EP5, 12BD, 12CH,1 7BD, 17CVI, and 17EI.

17 Environment 1 to 11 heading date are: 11BD, 11EP1, 11EP2, 11EP3, 11EP4, 11EP5, 12BD, 12CH, 17BD, 17CVI, and 17EI.

18 Mega-environments for traits: YLD had ME1 (11CH, 14EP4, 14EP5, 17BI, and 17CVI), ME2 (11BD, 11EP5, 12BD,12EP1, 12EP2, and 17EI), ME3 (12CH,

19 12UVD, 13UVL, and 17BD), and ME4 (12UV5, 12UV7, 12UVL, and 14CH); TW had ME1 (12BD, 12EP2, 12UV7, 12UVL, 12UV5, 13EP3, and 14CH) and 20 ME2 (11EP5, 12CH, 12EP1, 12EP3, 13EP2, 13EP4, 13EP5, 14EP4, 14EP5, 17BD, 17BI, and 17EI). HT had ME1 (11EP3, 11BD, 12BD, 17CVI, 12CH), ME2 21 (11EP1, 11EP2, 11EP4, 11EP5, 17BD, 17EI). HD had ME1 (12EP2, 11EP4, 11BD, 12EP1, 17BD) and ME2 (12EP3, 12BD, 11EP5, 11EP1, 11EP3).

22 d Linkage group.

23 'Centi Morgan distance.

$24{ }^{\mathrm{f}}$ QTL 95\% confidence interval

25 g Logarithm of odds, A, LOD due to A; A*E, LOD due to $\mathrm{A} * \mathrm{E}$ interaction.

26 h Phenotypic variance explained, A, PVE explained by Additive effect, A*E, PVE by additive-by-environment interaction effect.

27 i Additive effects of the QTL. Positive value indicates the favorable allele came from female parent TAM 112 and negative value indicates the favorable allele 28 came from male parent TAM 111. 


\section{Figure 1}

GGE-Biplot analysis of yield and agronomic traits to classify mega-environments for each trait. Clusters of environments within a quadrant is in a mega-environment

ME1, ME2, ME3, ME4 are mega-environment 1, 2, 3, and 4 where lines performed very similarly. Individual Environments were Bushland, TX in 2011, 2012, 2017 as dryland (11BD, 12BD, 17BD), irrigated in 2017 (17BI), Chillicothe, TX in 2011, 2012 and 2014 as dryland $(11 \mathrm{CH}, 12 \mathrm{CH}, 14 \mathrm{CH})$, Etter, TX with five irrigation levels (40\%, 50\%, 65\%,75\% and $100 \%)$ in 2011 (11EP1, 11EP2, 11EP3, 11EP4, 11EP5), three irrigation levels in 2012 (12EP1, 12EP2, 12EP3), four irrigation levels in 2013 (13EP2, 13EP3, 13EP4, 13EP5), two irrigation levels in 2014 (14EP4, 14EP5), and irrigated in 2017 (17El), Uvalde, TX in 2012 as dryland (12UVLD = 12UVD), and with three irrigation levels in 2012 (50\%, 75\%, 100\%) (12UV5, 12UV7, 12UVL), irrigated in 2013 (13UVL), Clovis, NM irrigated in 2017 (17CVI). Me's for traits were a) heading days, b) plant height, c) test weight, ME1 included 12BD, 12EP2, 12UV7, 12UVL, 12UV5, 13EP3, and 14CH; ME2 included 11EP5, 12CH, 12EP1, 12EP3, 13EP2, 13EP4, 13EP5, 14EP4, 14EP5, 17BD, 17BI, and 17El; d) grain yield, ME1 included 11CH, 14EP4, 14EP5, 17BI, and 17CVI; ME2 included 11BD, 11EP5, 12BD,12EP1, 12EP2, 17El; ME3 included 12CH, 12UVD, 13UVL,17BD; ME4 included 12UV5, 12UV7, 12UVL, and 14CH. 
1

2

3

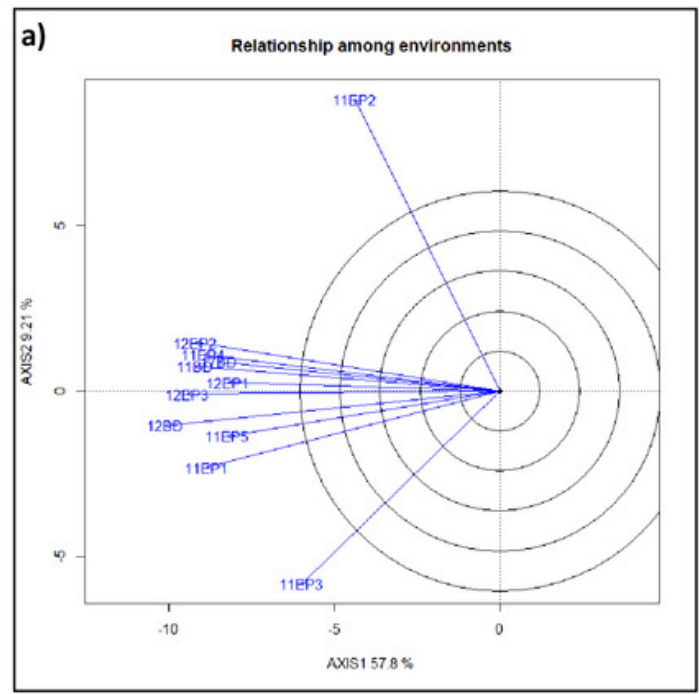

4

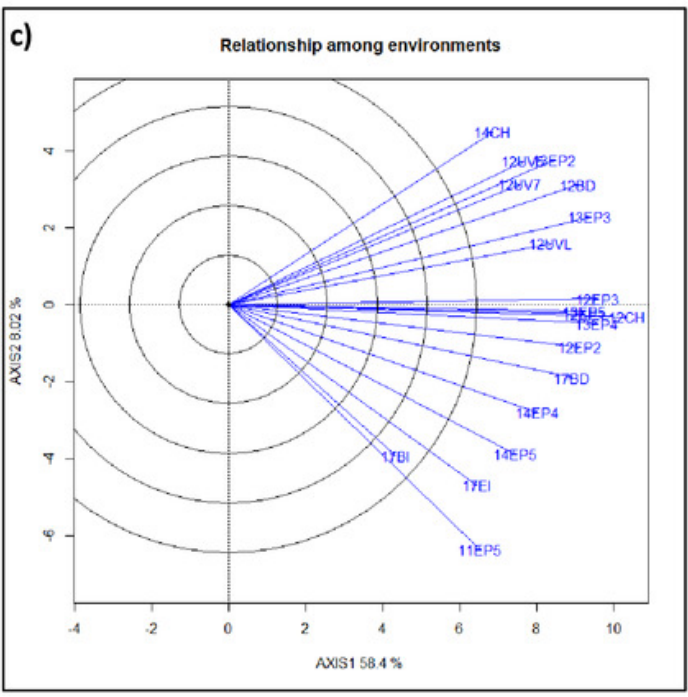

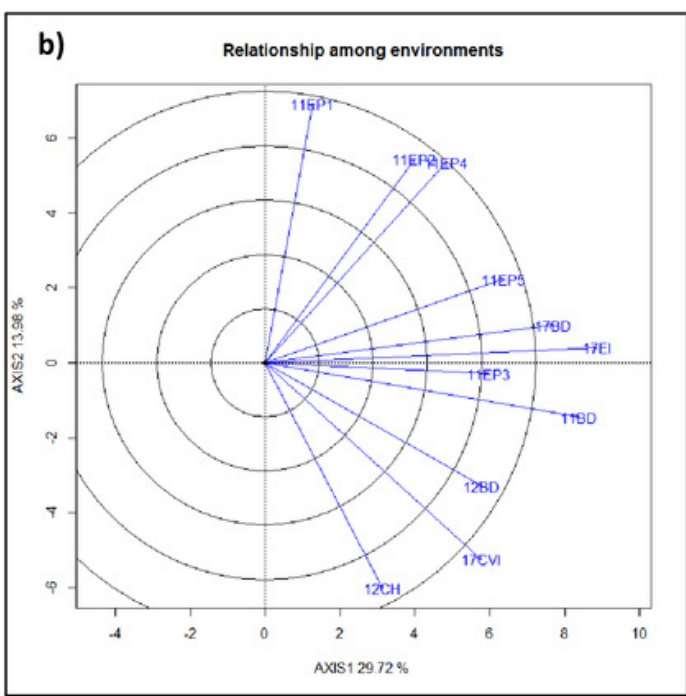

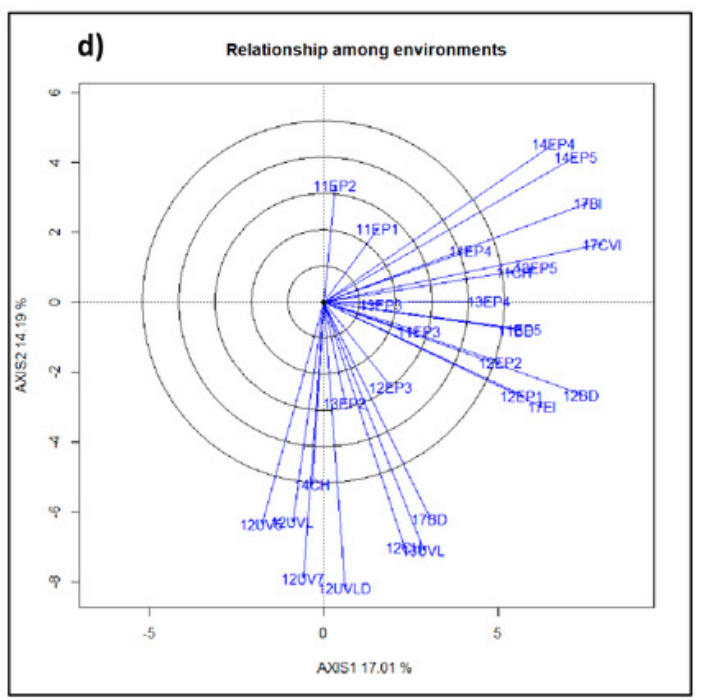

6

7 


\section{Figure 2}

Genetic maps showing the positions of QTL for grain yield and agronomic traits from QTL analysis in TAM $112 \times$ TAM 111 RIL population

Markers are represented by horizontal stripes inside a linkage group. Traits include grain yield (YLD), test weight (TW), plant height (HT), and heading date (HD). Identified QTL were designated in the format as Qtrait.tamu.chrom.Mb. The bar length is the flanking marker intervals in $\mathrm{cM}$. 

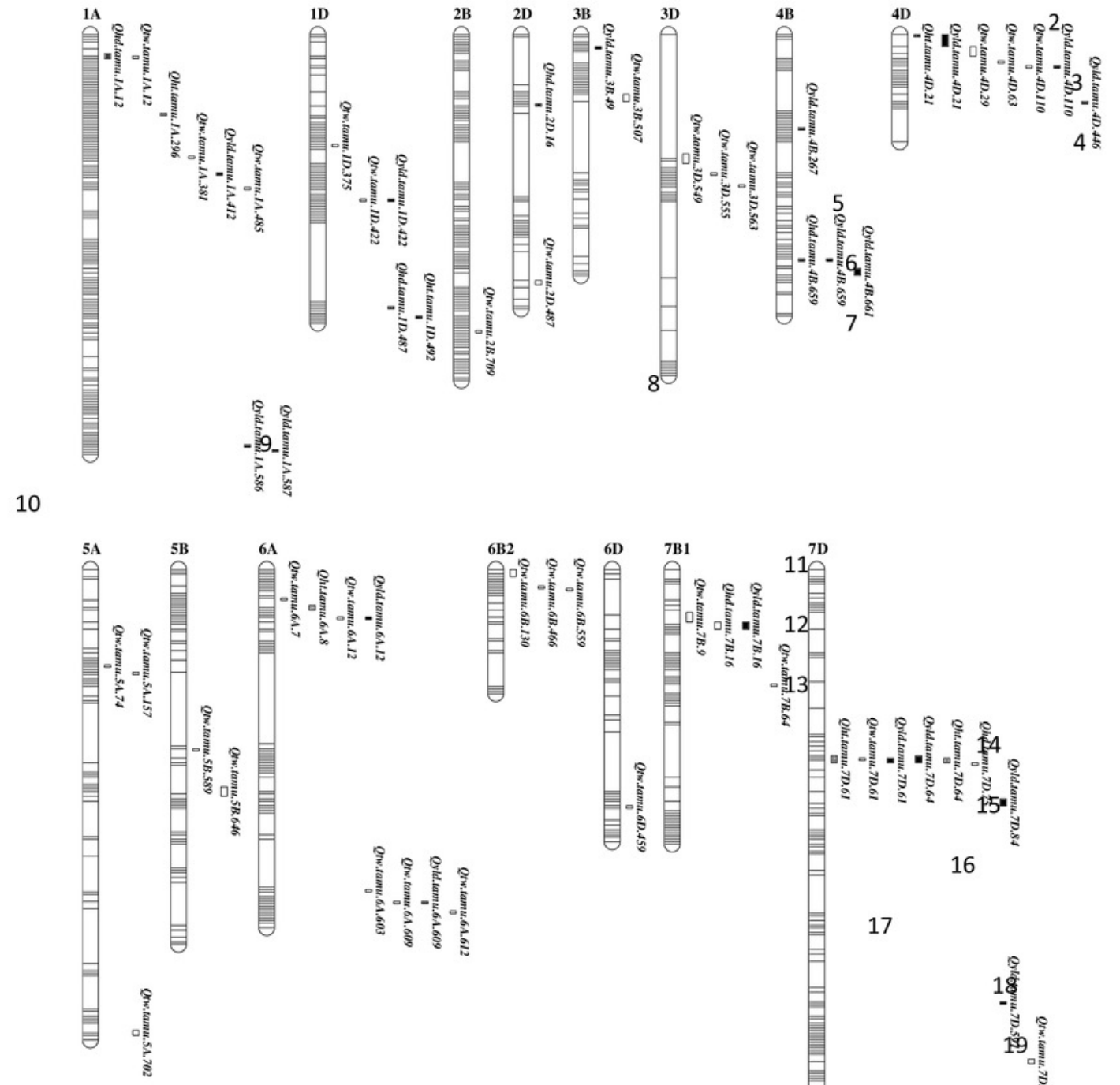

20

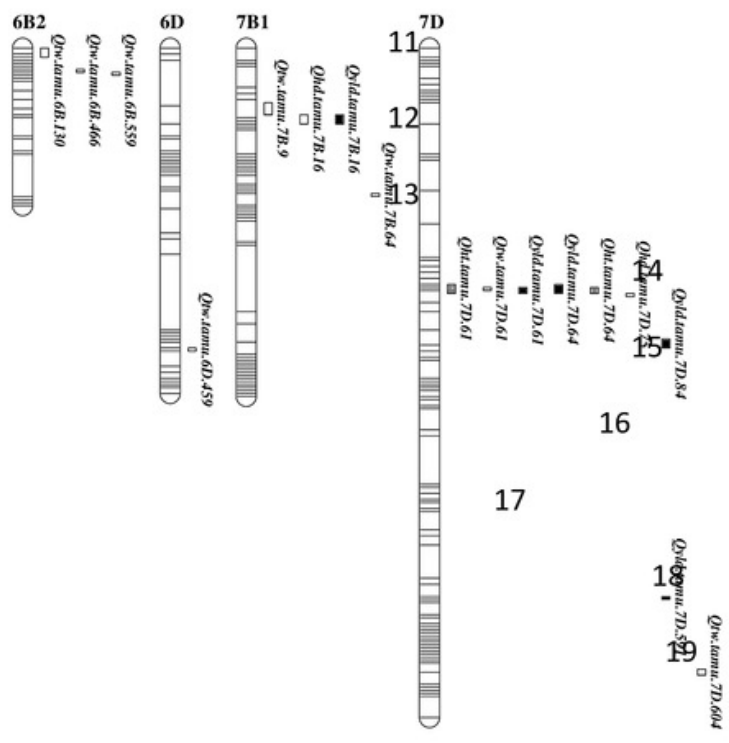

